\title{
A Complex Relationship between Visfatin and Resistin and microRNA: An In Vitro Study on Human Chondrocyte Cultures
}

\author{
Sara Cheleschi ${ }^{1}$, Nicola Giordano ${ }^{2}$, Nila Volpi ${ }^{3}$, Sara Tenti ${ }^{1}$, Ines Gallo ${ }^{1}$, Martina Di Meglio ${ }^{4}$, \\ Stefano Giannotti ${ }^{4}$ and Antonella Fioravanti ${ }^{1, *(1)}$ \\ 1 Rheumatology Unit; Department of Medicine, Surgery and Neuroscience, Azienda Ospedaliera \\ Universitaria Senese, Policlinico Le Scotte, 53100 Siena, Italy; saracheleschi@hotmail.com (S.C.); \\ sara_tenti@hotmail.it (S.T.); ins.gll3@gmail.com (I.G.) \\ 2 Scleroderma Unit, Department of Medicine, Surgery and Neuroscience, University of Siena, Policlinico \\ Le Scotte, 53100 Siena, Italy; nicola.giordano@unisi.it \\ 3 Neurology Unit, Department of Medicine, Surgery and Neuroscience, Azienda Ospedaliera Universitaria \\ senese, Policlinico Le Scotte, 53100 Siena, Italy; nila.volpi@unisi.it \\ 4 Department of Medicine, Surgery and Neurosciences, Section of Orthopedics and Traumatology, \\ University of Siena, Policlinico Le Scotte, 53100 Siena, Italy; martina.dimeglio@gmail.com (M.D.M.); \\ stefano.giannotti@unisi.it (S.G.) \\ * Correspondence: fioravanti7@virgilio.it; Tel.: +39-0577-233345; Fax: +39-0577-40450
}

Received: 24 October 2018; Accepted: 5 December 2018; Published: 6 December 2018

\begin{abstract}
Growing evidence indicates the important role of adipokines and microRNA (miRNA) in osteoarthritis (OA) pathogenesis. The purpose of the present study was to investigate the effect of visfatin and resistin on some miRNA (34a, 140, 146a, 155, 181a, let-7e), metalloproteinases (MMPs), and collagen type II alpha 1 chain (Col2a1) in human OA chondrocytes and in the T/C-28a2 cell line. The implication of nuclear factor (NF) $-\kappa B$ in response to adipokines was also assessed. Chondrocytes were stimulated with visfatin (5 or $10 \mu \mathrm{g} / \mathrm{mL}$ ) and resistin (50 or $100 \mathrm{ng} / \mathrm{mL}$ ) with or without NF- $\mathrm{kB}$ inhibitor (BAY-11-7082, $1 \mu \mathrm{M}$ ) for $24 \mathrm{~h}$. Viability and apoptosis were detected by MMT and cytometry, miRNA, MMP-1, MMP-13, and Col2a1 by qRT-PCR and NF- $\kappa B$ activation by immunofluorescence. Visfatin and resistin significantly reduced viability, induced apoptosis, increased miR-34a, miR-155, miR-181a, and miR-let7e, and reduced miR-140 and miR-146a gene expression in OA chondrocytes. $M M P-1, M M P-13$, and Col2a1 were significantly modulated by treatment of OA chondrocytes with adipokines. Visfatin and resistin significantly increased NF- $\mathrm{kB}$ activation, while the co-treatment with BAY11-7082 did not change MMPs or Col2a1 levels beyond that caused by single treatment. Visfatin and resistin regulate the expression levels of some miRNA involved in OA pathogenesis and exert catabolic functions in chondrocytes via the $N F-\kappa B$ pathway. These data confirm the complex relationship between adipokines and miRNA.
\end{abstract}

Keywords: visfatin; resistin; adipokines; osteoarthritis; miRNA; chondrocyte; T/C-28a2; NF-kB

\section{Introduction}

Osteoarthritis (OA) represents the most widespread chronic degenerative joint disorder and is a leading cause of chronic disability, impairment, and reduced quality of life in adult and elderly populations [1]. Osteoarthritis is generally accepted to be caused by physical and chemical degenerative changes of the joint tissue, resulting in a progressive degeneration of articular cartilage, osteophyte formation, and synovial membrane low-grade inflammation, leading to the loss of function and pain [2-5]. 
Obesity constitutes one of the most important risk factors for OA in non-weight and weight bearing joints [6-9].

Growing evidence indicates that white adipose tissue is an active endocrine organ producing multiple factors, known as adipocytokines, such as interleukin (IL)-6, tumor necrosis factor (TNF)- $\alpha$, as well as adipokines: adiponectin, leptin, resistin, chemerin, and visfatin [10]. Adipokines have shown pleiotropic effects modulating the immune response and affecting bone and cartilage metabolisms [10,11].

Recently, resistin has received more attention for its involvement in cartilage damage. In human OA chondrocyte cultures, resistin induces the expression of different pro-inflammatory cytokines and chemokines, as well as of metalloproteinases (MMP)-1, MMP-13, and a disintegrin and metalloproteinase with thrombospondin motifs (ADAMTS)-4 [12]. Serum levels of resistin are increased in patients with OA of the hand $[13,14]$ and in serum and synovial fluid of patients with knee OA [15-17].

Visfatin has pro-inflammatory, immunomodulating, and pro-degradative effects on cartilage [18-20]. Serum visfatin levels are increased in patients with knee or hand OA [14,21,22].

MicroRNA (miRNA) are 22-25 nucleotides and non-coding, single-stranded RNA molecules which act in post-transcriptional regulation of gene expression either through enhancement or degradation of the target gene messenger RNA (mRNA) [23]. Different miRNA expression profiles were observed in OA cartilage with respect to normal samples [24-29]. Some miRNA dysregulated in OA target genes encoding for proteins implicated in extracellular matrix remodeling and in pro-inflammatory activities [30,31].

A mutual interaction between miRNA and adipokines has been recently reported; miRNA modulate adipocyte differentiation in mouse and human cell line models, and some adipokines are involved in the regulation of miRNA expression [32,33].

On the basis of these considerations we hypothesized the possible involvement of adipokines in the regulation of some miRNA implicated in OA pathogenesis.

For this purpose, we investigated the possible effect of visfatin and resistin in the viability and apoptosis, as well as in the regulation of the expression levels of a pattern of miRNA ( $m i R-34 a, m i R-146 a$, miR-155, miR-181a, miR-140, and miR-let7e) in human OA chondrocyte cultures and in T/C-28a2 cell lines. The modifications of the main extracellular matrix-degrading enzymes, $M M P-1, M M P-13$, and of collagen type II alpha 1 chain (Col2a1) were also analyzed. Moreover, the possible involvement of the nuclear factor (NF)- $\kappa B$ signaling pathway was investigated by means of immunofluorescence (IF) and semi-quantitative analysis, and by using a specific NF- $\kappa B$ inhibitor.

\section{Results}

\subsection{Cell Viability Assay}

Cell viability evaluated by MTT test is reported in Figure 1. A significant decrease in the percentage of survival cells was observed after stimulus of OA chondrocytes with visfatin $5 \mu \mathrm{g} / \mathrm{mL}$ and $10 \mu \mathrm{g} / \mathrm{mL}(p<0.05, p<0.01$, respectively, Figure $1 \mathrm{~A})$ and resistin $50 \mathrm{ng} / \mathrm{mL}$ and $100 \mathrm{ng} / \mathrm{mL}(p<0.05$, $p<0.01$, respectively, Figure 1B), in comparison to basal conditions in a dose-dependent manner. No modification in the T/C-28a2 cell line was observed. The data was confirmed by Trypan Blue test. 


\section{Cell Viability}

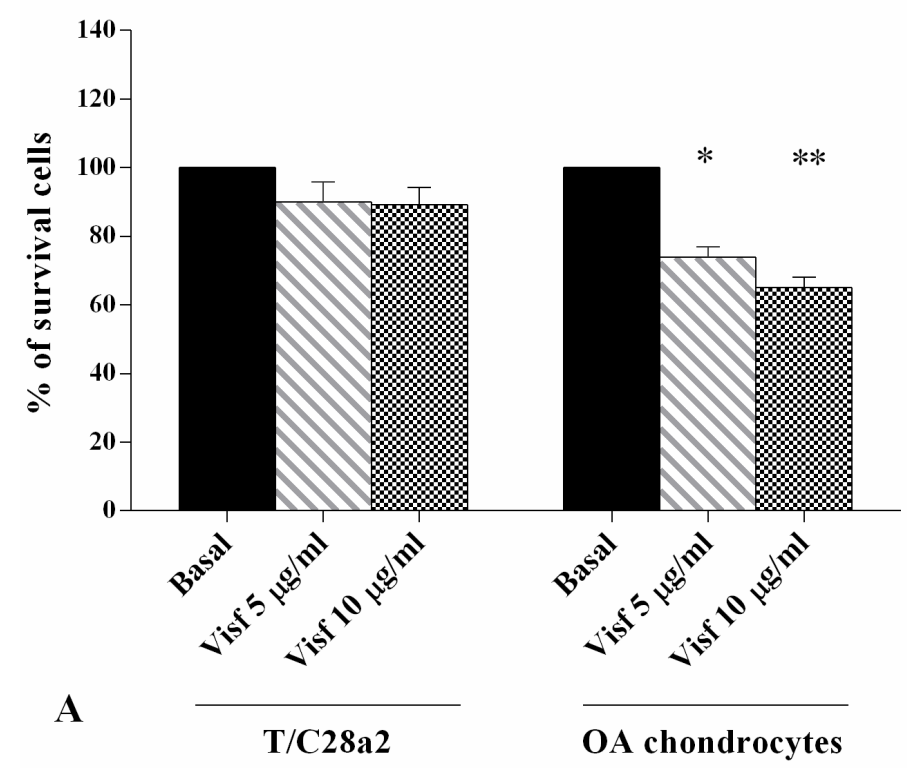

\section{Cell Viability}

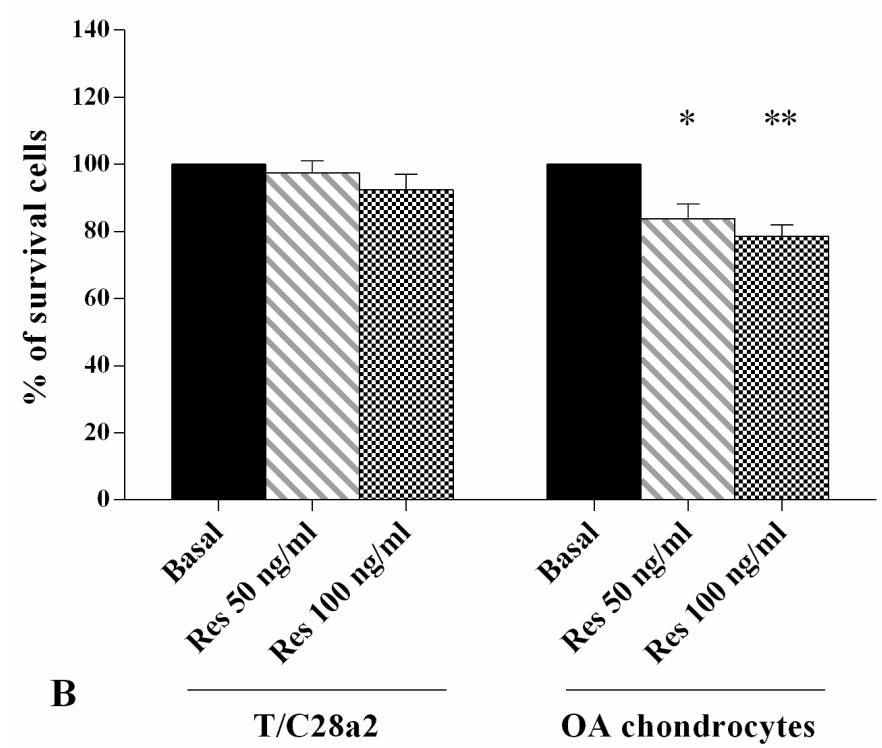

Figure 1. Evaluation of cell viability by MTT assay in the T/C-28a2 cell line and in human OA chondrocytes. Cells were evaluated at basal conditions and after $24 \mathrm{~h}$ of stimulus with visfatin $(5 \mu \mathrm{g} / \mathrm{mL}$ and $10 \mu \mathrm{g} / \mathrm{mL})(\mathbf{A})$ and resistin $(50 \mathrm{ng} / \mathrm{mL}$ and $100 \mathrm{ng} / \mathrm{mL})(\mathbf{B})$. Data were expressed as percentage of cell viability in all the studied conditions. The percentage was referenced to the ratio of the value of interest and basal conditions. The value of basal conditions was reported equal to 100. Data were expressed as mean \pm SD of triplicate values. ${ }^{*} p<0.05,{ }^{* *} p<0.01$ versus basal conditions. Visf $=$ Visfatin, Res $=$ Resistin .

\subsection{Apoptosis Detection}

Figure 2 summarizes the results on the ratio of chondrocyte apoptosis obtained by flow cytometry analysis. The stimulus of OA cells with visfatin $5 \mu \mathrm{g} / \mathrm{mL}$ and $10 \mu \mathrm{g} / \mathrm{mL}$ induced a significant increase of apoptotic chondrocytes $(p<0.05, p<0.01$, respectively, Figure $2 \mathrm{~A})$ in comparison 
to the basal time. Resistin at a concentration of $50 \mathrm{ng} / \mathrm{mL}$ and $100 \mathrm{ng} / \mathrm{mL}$ also determined a statistically increase of the apoptosis ratio $(p<0.05, p<0.01$, respectively, Figure $2 \mathrm{~B})$. No detectable changes were observed in T/C-28a2 cell line.
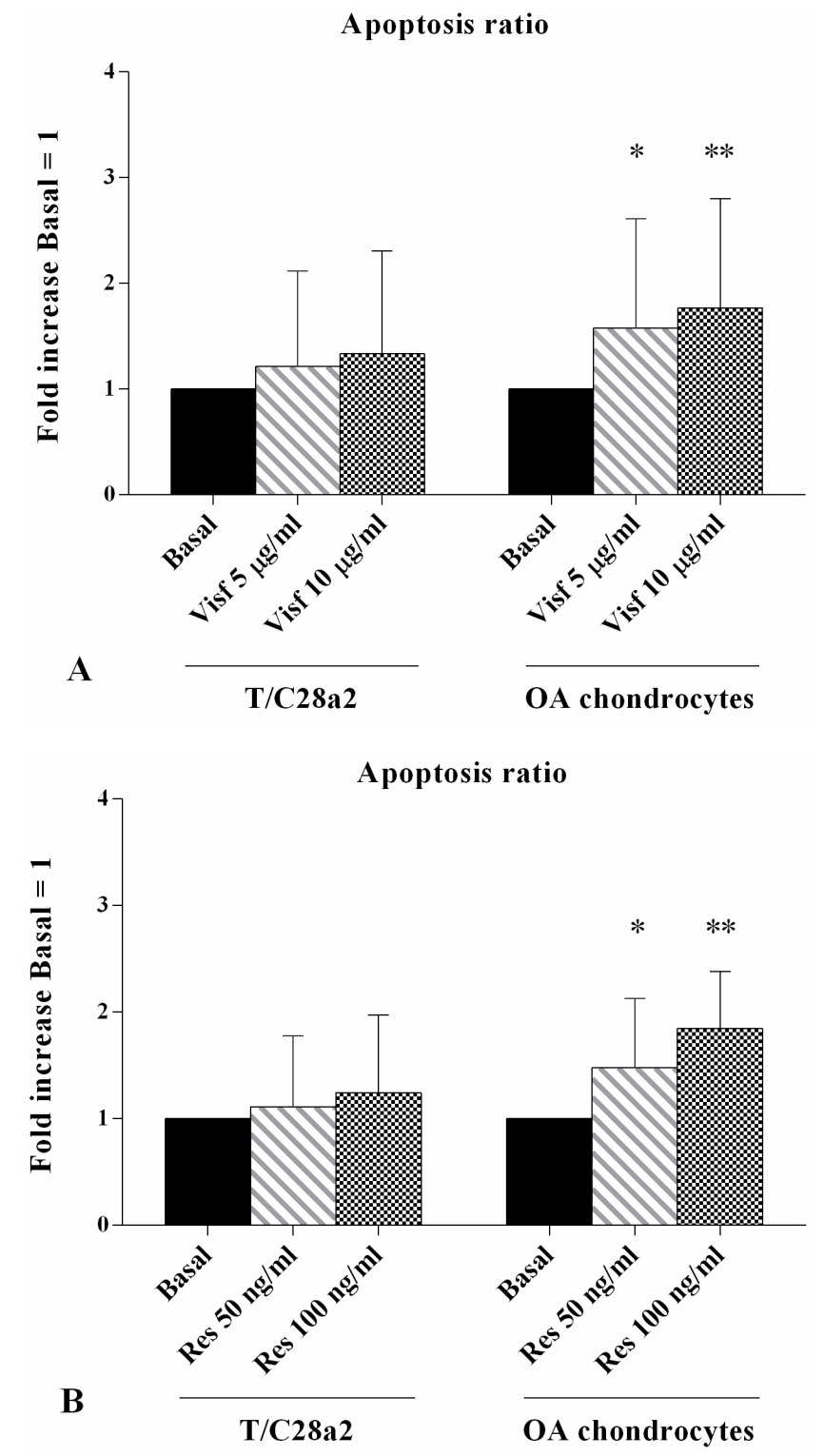

Figure 2. Apoptosis detection by flow cytometry in T/C-28a2 cell line and in human osteoarthritis (OA) chondrocytes. Cells were evaluated at basal conditions and after $24 \mathrm{~h}$ of stimulus with visfatin $(5 \mu \mathrm{g} / \mathrm{mL}$ and $10 \mu \mathrm{g} / \mathrm{mL})(\mathbf{A})$ and resistin $(50 \mathrm{ng} / \mathrm{mL}$ and $100 \mathrm{ng} / \mathrm{mL})(\mathbf{B})$. Apoptosis was measured with Annexin Alexa fluor 488 assay. Data were expressed as percentage of positive cells for Annexin-V and propidium iodide (PI) in all the studied conditions. The ratio of apoptosis was referenced to the ratio of the value of interest and basal conditions. The value of basal conditions was reported equal to 1 . Data were expressed as mean \pm SD of triplicate values. ${ }^{*} p<0.05,{ }^{* *} p<0.01$ versus basal conditions. Visf $=$ Visfatin, Res $=$ Resistin.

\subsection{Gene Expression of miRNA}

Visfatin $5 \mu \mathrm{g} / \mathrm{mL}$ and $10 \mu \mathrm{g} / \mathrm{mL}(p<0.01)$ induced a significant increase of miR-155 expression levels in the T/C-28a2 cell line, while it did not influence $m i R-34 a, m i R-140, m i R-146 a, m i R-181 a$, and miR-let7e expressions (Figure 3A). In OA chondrocytes (Figure 3B), visfatin, $5 \mu \mathrm{g} / \mathrm{mL}$ and $10 \mu \mathrm{g} / \mathrm{mL}$, was able to significantly decrease miR-140 and $m i R-146 a(p<0.01, p<0.05$, respectively) 
and significantly increase miR-let7e $(p<0.05)$ expression levels when compared with basal conditions. MiR-34a, miR-155, and miR-181a were significantly increased by the higher concentration of visfatin $(p<0.01, p<0.001, p<0.05$, respectively).

T/C28a2

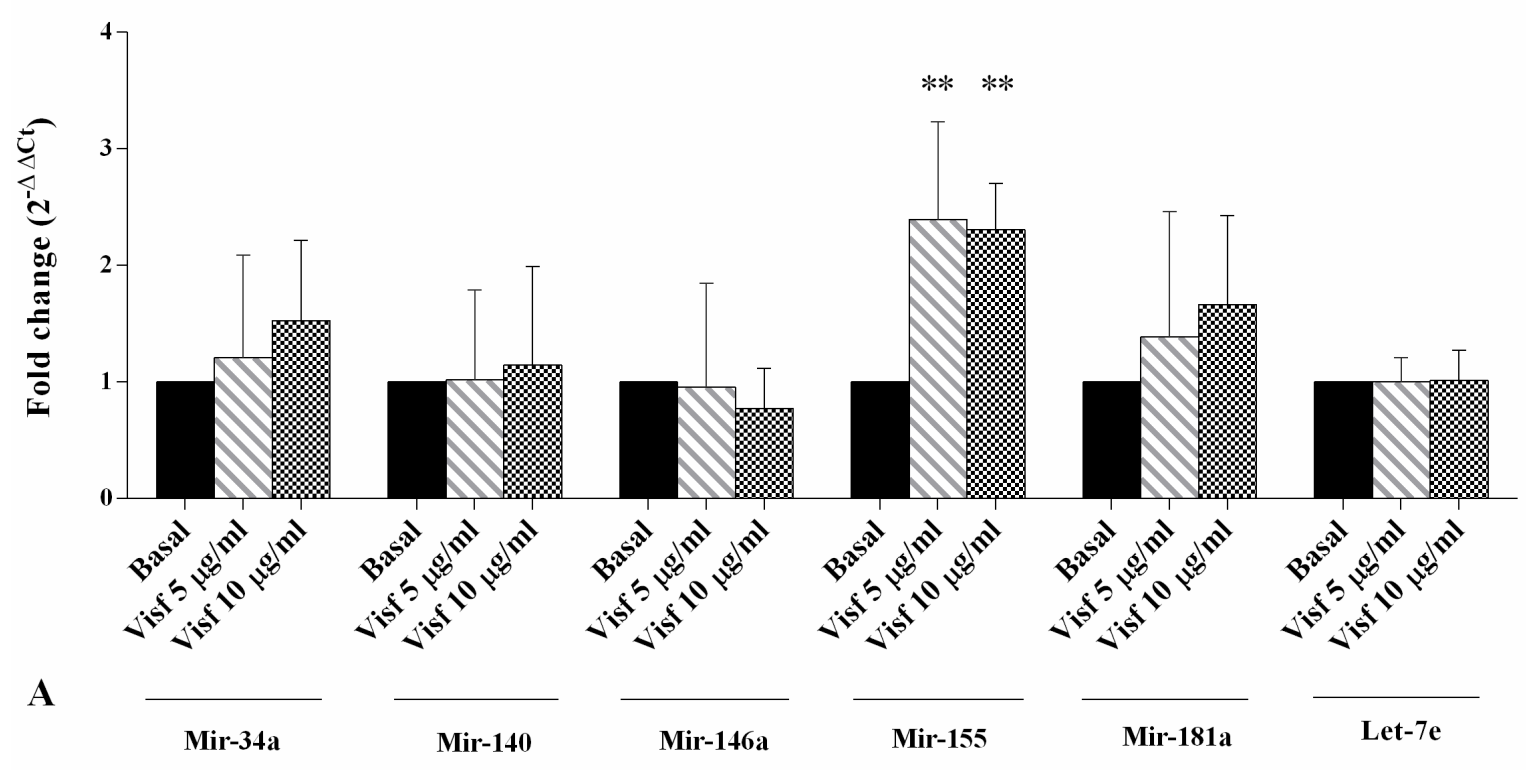

OA chondrocytes

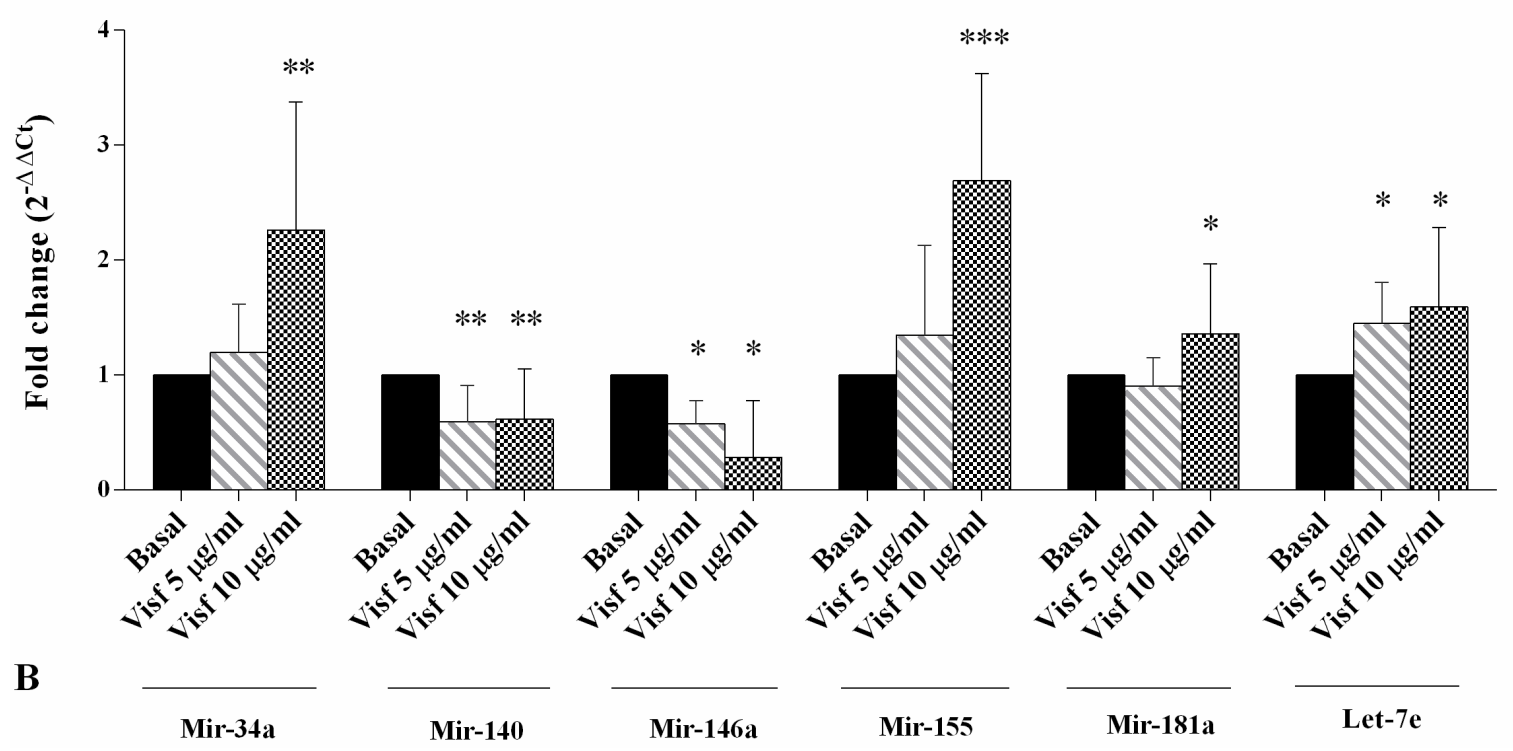

Figure 3. Cont. 


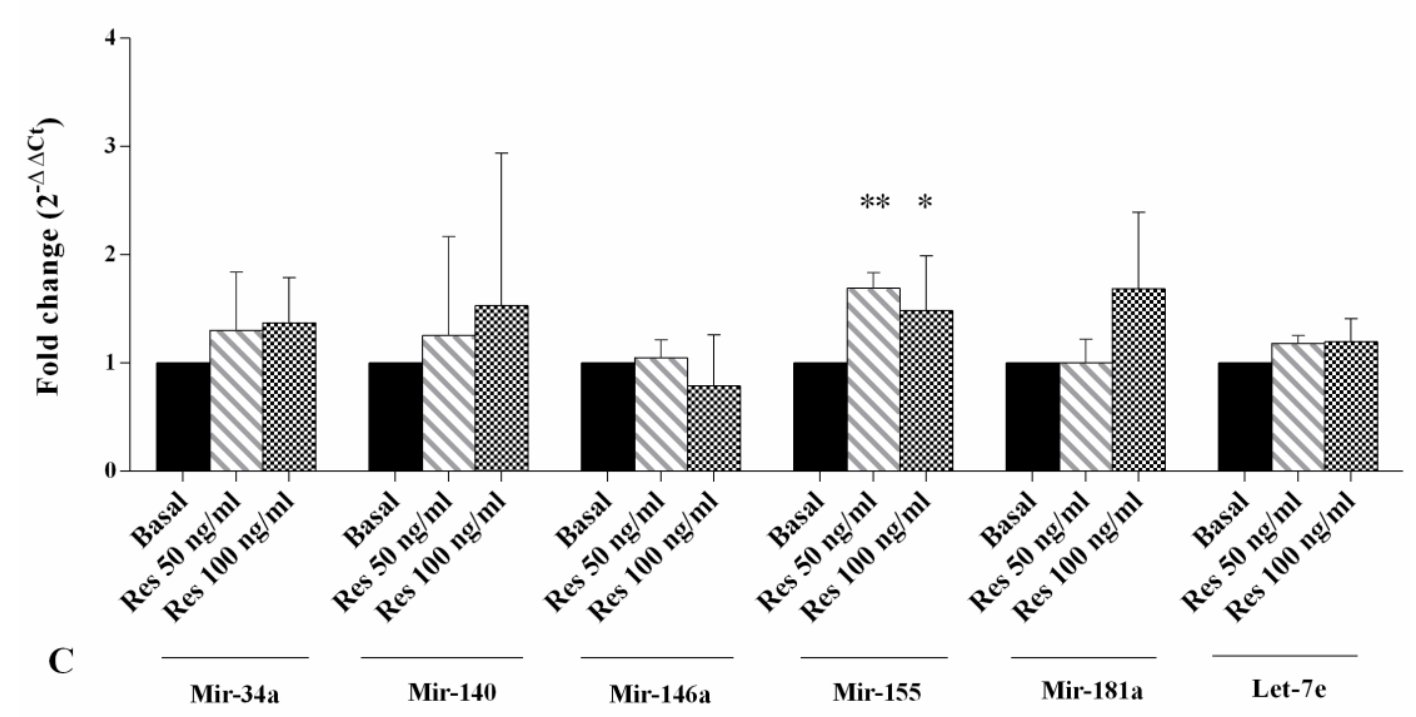

OA chondrocytes

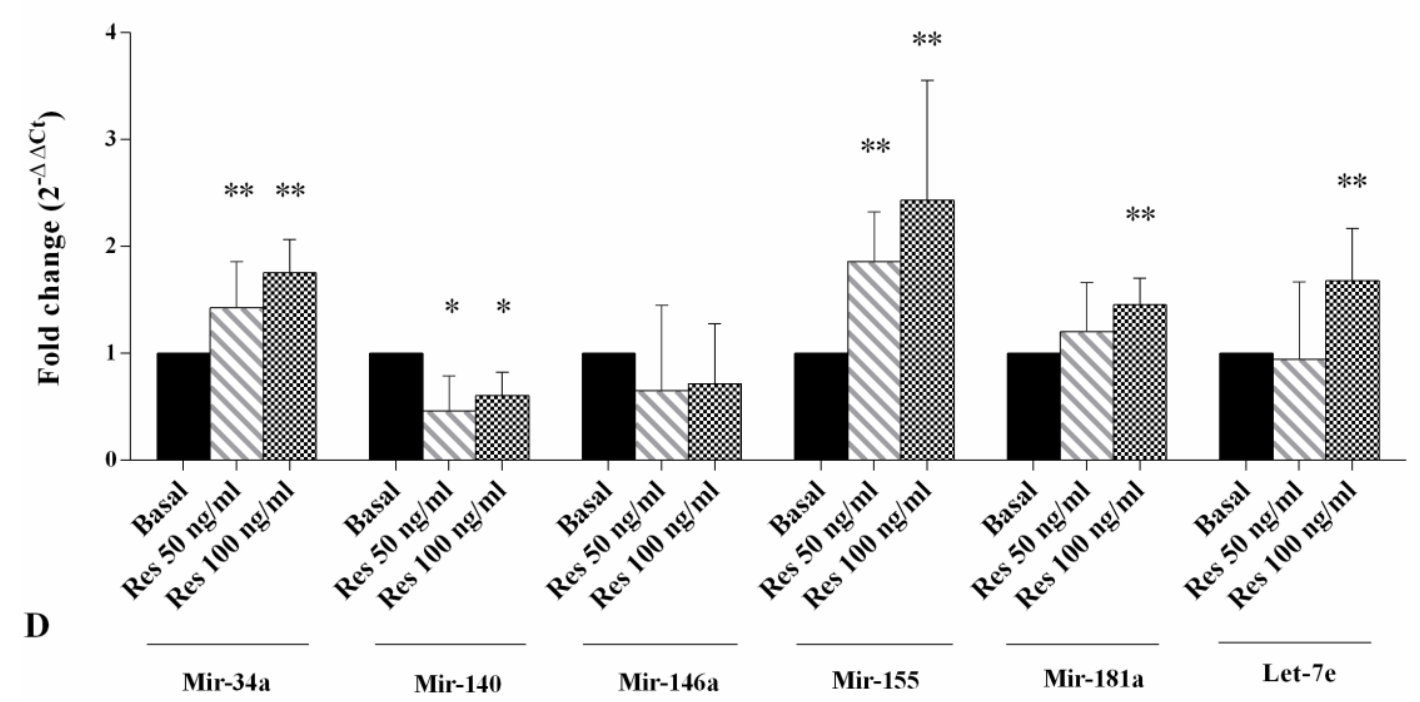

Figure 3. Expression levels of $m i R-34 a$, miR-140, miR-155, miR-181a, and miR-let7e by real-time PCR in the T/C-28a2 cell line $(A, C)$ and in human OA chondrocytes (B,D). Cells were evaluated at basal conditions and after $24 \mathrm{~h}$ of stimulus with visfatin $(5 \mu \mathrm{g} / \mathrm{mL}$ and $10 \mu \mathrm{g} / \mathrm{mL})$ and resistin $(50 \mathrm{ng} / \mathrm{mL}$ and $100 \mathrm{ng} / \mathrm{mL}$ ). The gene expression was referenced to the ratio of the value of interest and basal conditions. The value of basal conditions was reported equal to 1 . Data were expressed as mean \pm SD of triplicate values. ${ }^{*} p<0.05,{ }^{* *} p<0.01,{ }^{* * *} p<0.001$ versus basal conditions. Visf $=$ Visfatin, Res $=$ Resistin.

Resistin $50 \mathrm{ng} / \mathrm{mL}$ and $100 \mathrm{ng} / \mathrm{mL}$ significantly increased the expression levels of miR-155 $(p<0.01, p<0.05$, respectively) in the T/C-28a2 cell line in comparison to basal state (Figure 3C). Moreover, resistin at both studied concentrations induced a significant upregulation of miR-34a $(p<0.01)$, miR-155 $(p<0.01)$, miR-181a $(p<0.01$ for resistin $100 \mathrm{ng} / \mathrm{mL})$, and miR-let7e $(p<0.01$ for resistin $100 \mathrm{ng} / \mathrm{mL})$, and a downregulation of miR-140 $(p<0.05)$ gene expression in OA chondrocytes (Figure 3D). 


\subsection{Gene Expression of MMP-1, MMP-13, and Col2a1}

In $\mathrm{T} / \mathrm{C}-28 \mathrm{a} 2$ cell line, a significant increase of $M M P-1$ gene expression was observed after stimulus with visfatin $5 \mu \mathrm{g} / \mathrm{mL}$ and $10 \mu \mathrm{g} / \mathrm{mL}(p<0.01)$ in comparison to basal conditions. No changes were observed in MMP-13 and Col2a1 (Figure 4A). The incubation of OA chondrocytes with visfatin $5 \mu \mathrm{g} / \mathrm{mL}$ and $10 \mu \mathrm{g} / \mathrm{mL}$ determined a significant upregulation of MMP-1 $(p<0.01), M M P-13(p<0.05)$, and a downregulation of Col2a1 $(p<0.05)$ expression levels (Figure 4B).

Resistin $50 \mathrm{ng} / \mathrm{mL}$ significantly increased the gene expression of MMP-13 $(p<0.01)$ in the $\mathrm{T} / \mathrm{C}-28 \mathrm{a} 2$ cell line and upregulated the transcriptional levels of $M M P-1$ and $M M P-13$ when tested at concentration of $100 \mathrm{ng} / \mathrm{mL}(p<0.01)$, in comparison to basal time (Figure $4 \mathrm{C}$ ). In OA cells, the incubation with resistin $50 \mathrm{ng} / \mathrm{mL}$ and $100 \mathrm{ng} / \mathrm{mL}$ significantly increased the expression levels of $M M P-1(p<0.01$ for resistin $50 \mathrm{ng} / \mathrm{mL})$ and $M M P-13(p<0.05, p<0.01$, respectively) and decreased Col2a1 $(p<0.01)$ (Figure 4D).

\section{T/C28a2}

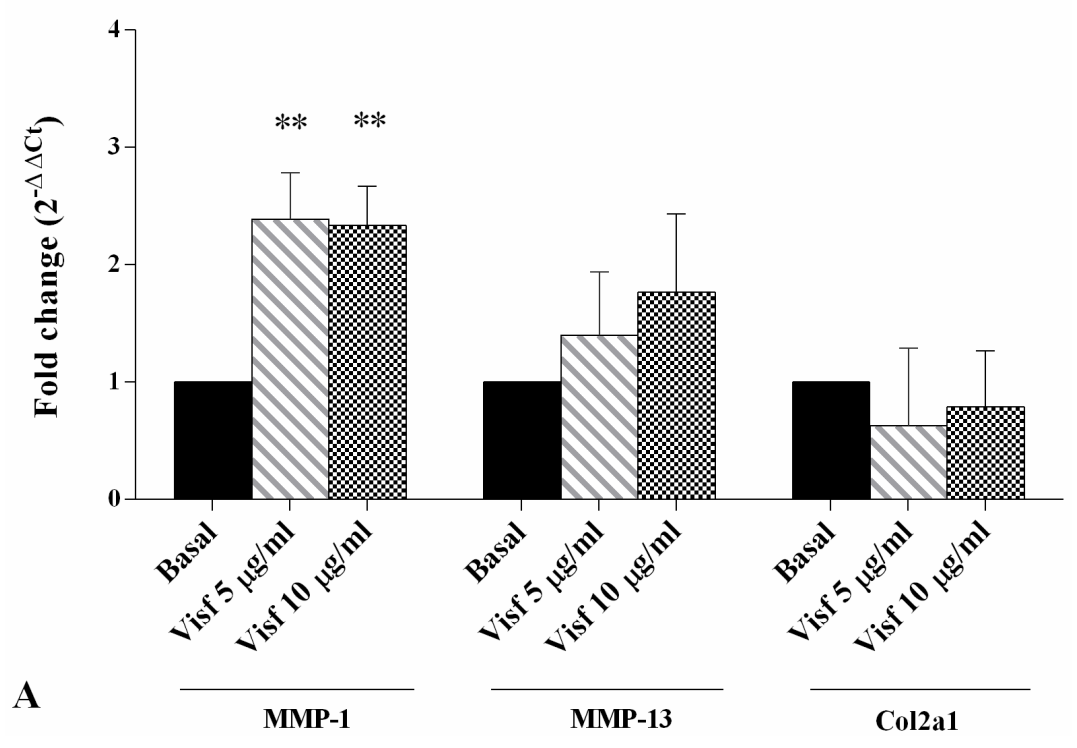

OA chondrocytes

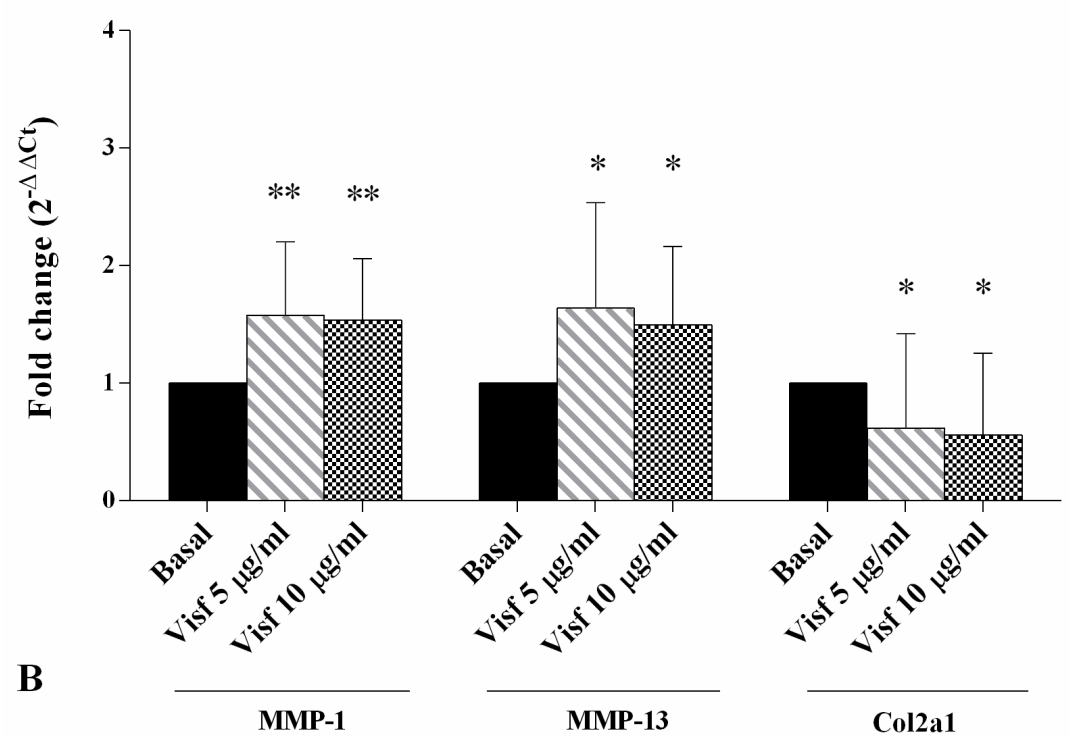

Figure 4. Cont. 
$\mathrm{T} / \mathrm{C28a2}$

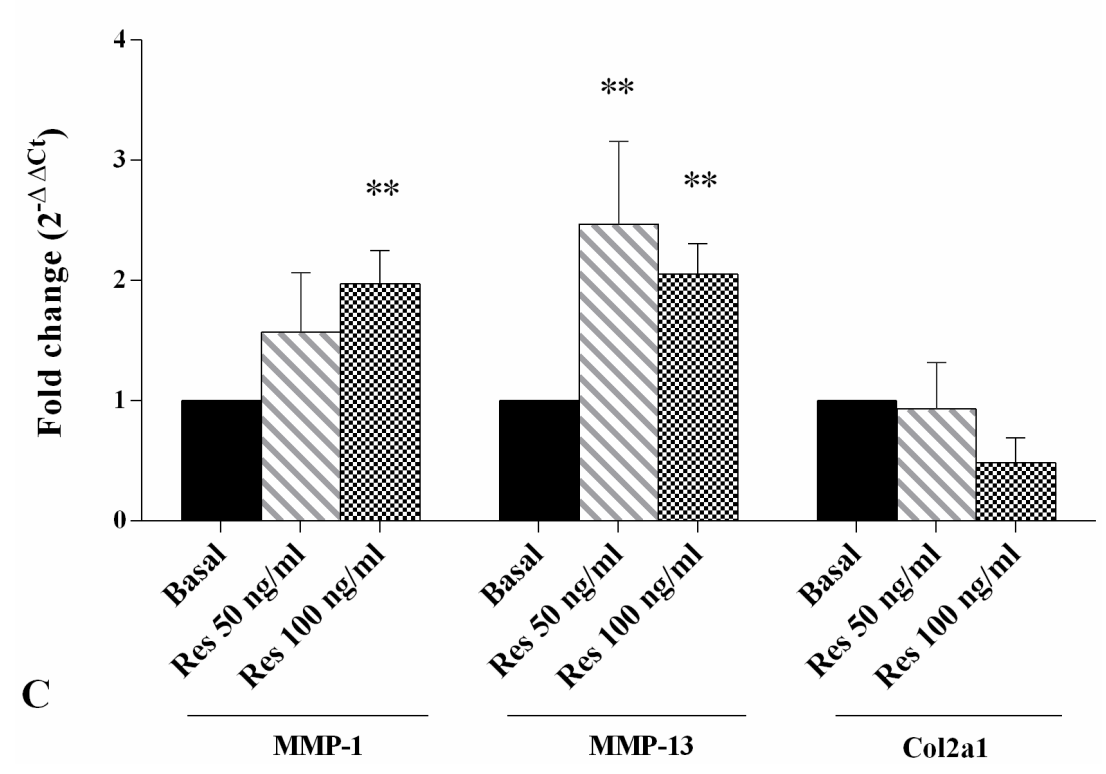

OA chondrocytes

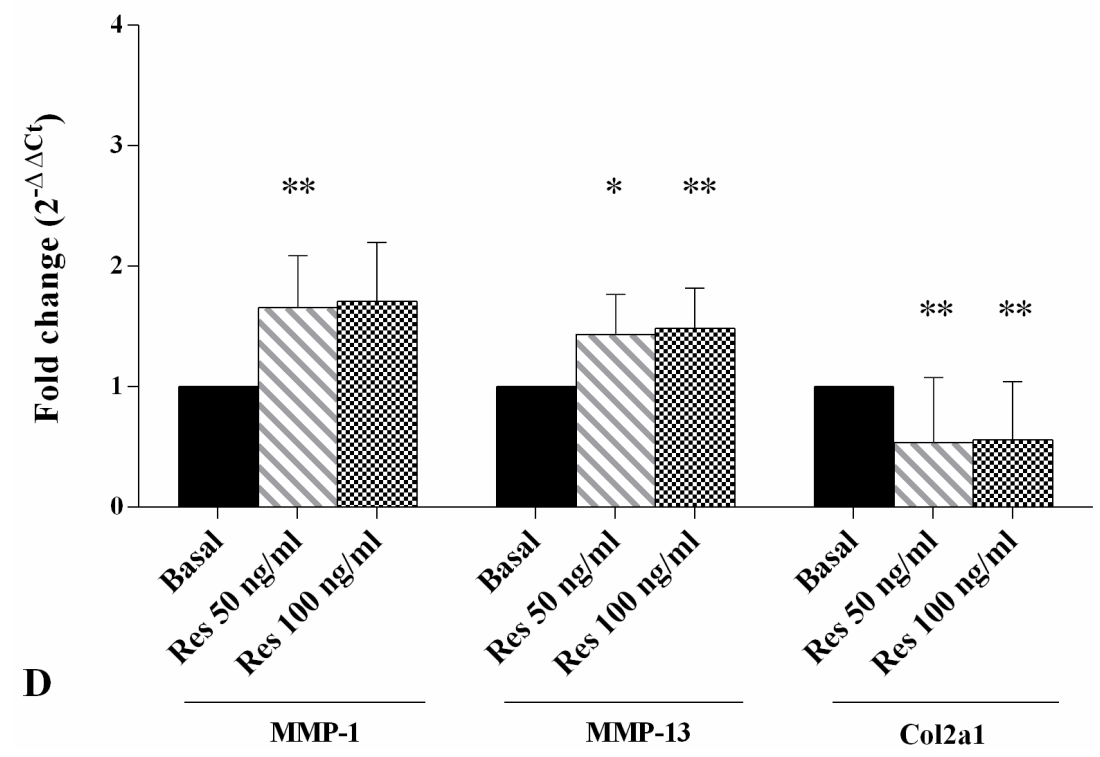

Figure 4. Expression levels of $M M P-1, M M P-13$, and Col2a1 by real-time PCR in the T/C-28a2 cell line $(\mathbf{A}, \mathbf{C})$ and in human OA chondrocytes (B,D). Cells were evaluated at basal conditions and after $24 \mathrm{~h}$ of stimulus with visfatin $(5 \mu \mathrm{g} / \mathrm{mL}$ and $10 \mu \mathrm{g} / \mathrm{mL})$ and resistin $(50 \mathrm{ng} / \mathrm{mL}$ and $100 \mathrm{ng} / \mathrm{mL})$. The gene expression was referenced to the ratio of the value of interest and basal conditions. The value of basal conditions was reported equal to 1 . Data were expressed as mean \pm SD of triplicate values. ${ }^{*} p<0.05$, ${ }^{* *} p<0.01$ versus basal conditions. Visf $=$ Visfatin, Res $=$ Resistin.

\subsection{Immunofluorescence Analysis}

Figure $5 \mathrm{~A}, \mathrm{~B}$ reported the activation and the nuclear translocation of the $N F-\kappa B$ subunit in OA chondrocytes. The signal of p50 NF- $\kappa B$ was consistently detected in the cytoplasm and in the nucleus at basal conditions. Visfatin and resistin significantly increased p50 cytoplasmic synthesis $(p<0.001$, Figure 5A), with a resulting higher immunolabelling intensity, as well as its activation, as indicated by nuclear translocation $(p<0.001$, Figure $5 B)$, in comparison to baseline. 
p50 cellular expression

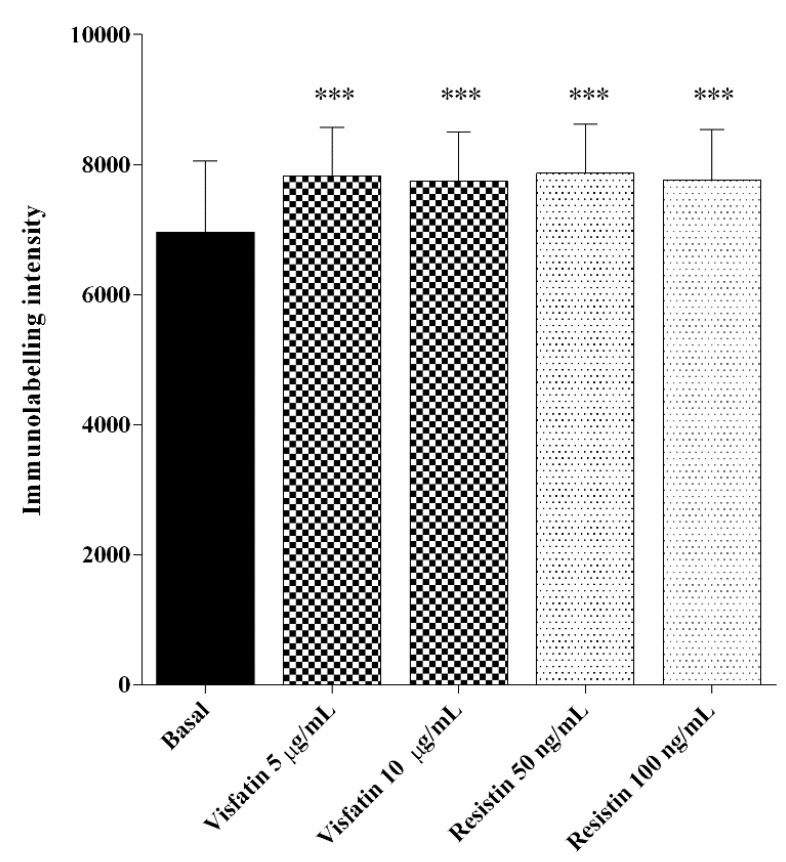

A

p50 nuclear expression

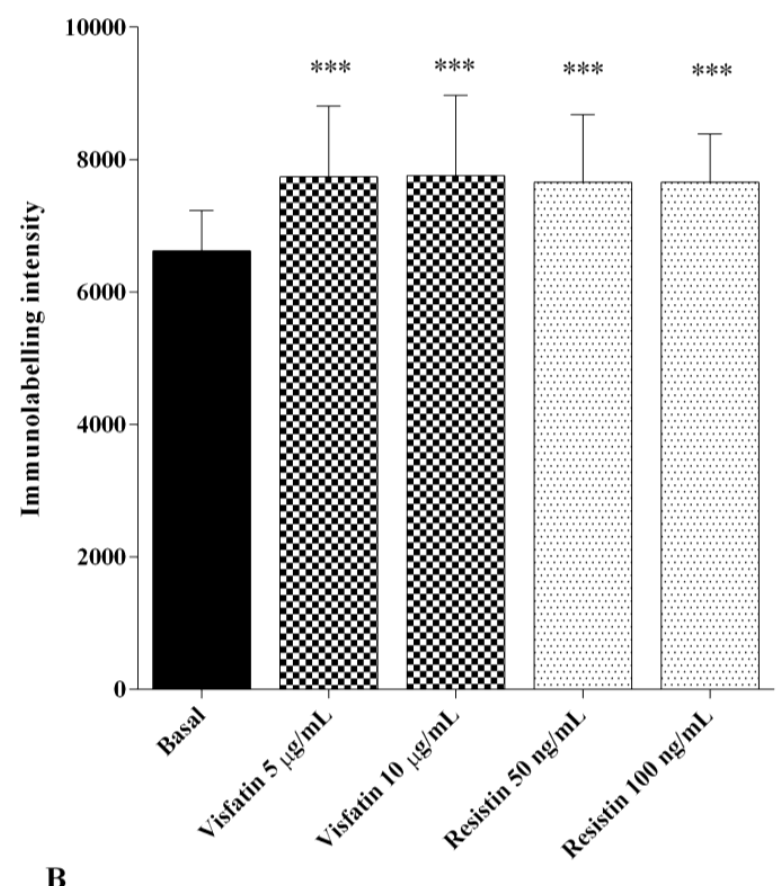

Figure 5. Immunofluorescence labelling of p50 NF- $\kappa B$ subunit localization of human OA chondrocytes. Cells were evaluated at basal conditions and after $24 \mathrm{~h}$ of stimulus with visfatin $(5 \mu \mathrm{g} / \mathrm{mL}$ and $10 \mu \mathrm{g} / \mathrm{mL}$ ) and resistin (50 $\mathrm{ng} / \mathrm{mL}$ and $100 \mathrm{ng} / \mathrm{mL}$ ). In chondrocytes stimulated with adipokines, p50 cytoplasmic upregulation and p50 nuclear translocation were observed (A,B) The histograms of immunolabelling intensity were plotted for the nuclear and cytoplasm expression for p50 subunit. $* * * p<0.001$ versus basal conditions. 


\subsection{Regulation of Gene Expression of MMP-1, MMP-13 and Col2a1 after NF- $\kappa B$ Inhibition}

In Figure 6 we showed that the incubation of OA chondrocytes with visfatin $(5 \mu \mathrm{g} / \mathrm{mL}$ and $10 \mu \mathrm{g} / \mathrm{mL})$ and resistin $(50 \mathrm{ng} / \mathrm{mL}$ and $100 \mathrm{ng} / \mathrm{mL})$ significantly upregulated $M M P-1(p<0.05$ for visfatin $5 \mu \mathrm{g} / \mathrm{mL}$ and $10 \mu \mathrm{g} / \mathrm{mL}$, and resistin $50 \mathrm{ng} / \mathrm{mL}$, Figure 6A), MMP-13 ( $p<0.05$ for visfatin $5 \mu \mathrm{g} / \mathrm{mL}$ and $10 \mu \mathrm{g} / \mathrm{mL}$, and resistin $50 \mathrm{ng} / \mathrm{mL}$, Figure 6B) and downregulated Col2a1 $(p<0.05$, Figure $6 \mathrm{C}$ ) expression levels in comparison to basal conditions.

\section{MMP-1}

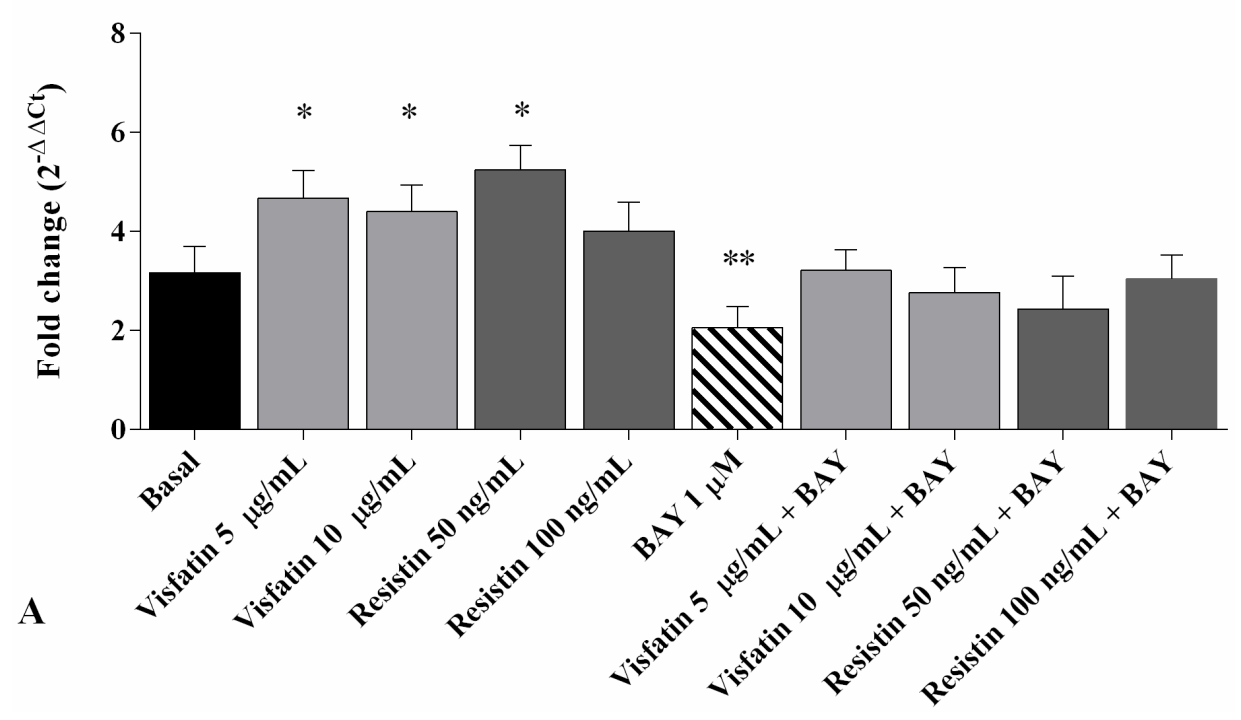

MMP-13

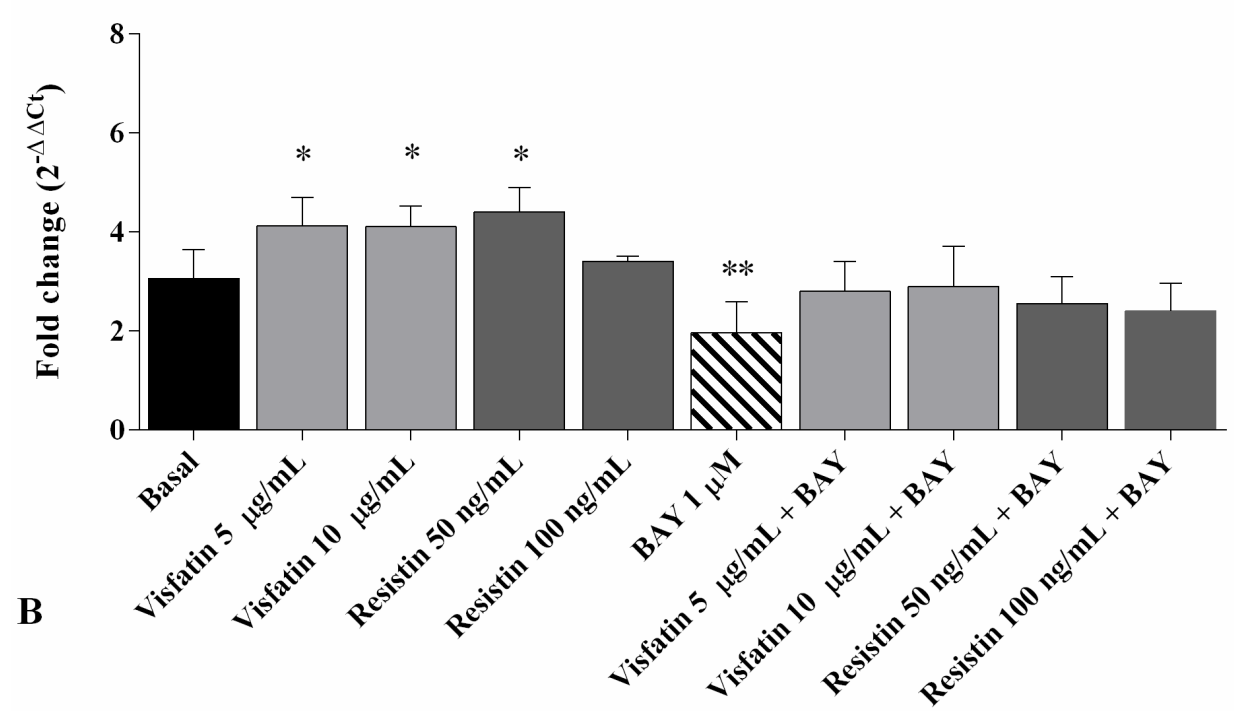

Figure 6. Cont. 


\section{Col2a1}

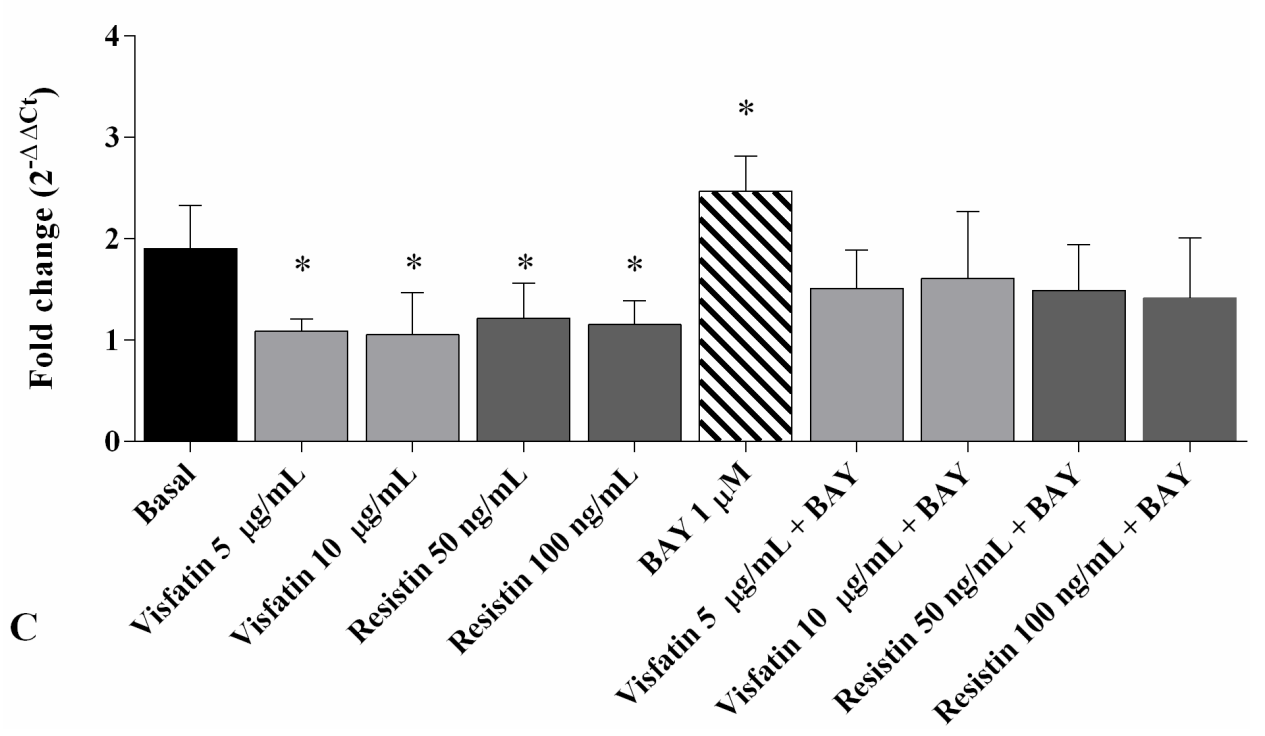

Figure 6. Expression levels of MMP-1 (A), MMP-13 (B), and Col2a1 (C) by real-time PCR in human OA chondrocytes. Cells were evaluated at basal conditions, pre-incubated for $2 \mathrm{~h}$ with $1 \mu \mathrm{M}$ BAY 11-7082 (NF- $\kappa B$ inhibitor) and after $24 \mathrm{~h}$ of stimulus with visfatin $(5 \mu \mathrm{g} / \mathrm{mL}$ and $10 \mu \mathrm{g} / \mathrm{mL})$ and resistin (50 ng/mL and $100 \mathrm{ng} / \mathrm{mL}$ ). Data were expressed as mean \pm SD of triplicate values. ${ }^{*} p<0.05,{ }^{* *} p<0.01$ versus basal conditions.

The pre-incubation of OA chondrocytes with a well-known NF- $\kappa B$ inhibitor, BAY 11-7082 $(\mathrm{IKK} \alpha / \beta)$, reduced MMP-1 $(p<0.01), M M P-13(p<0.01)$, and increased Col2a1 $(p<0.05)$ gene expression, in a significant manner, with respect to the basal state.

Chondrocytes co-treated with visfatin, resistin plus BAY11-7082 did not exhibit enhanced effects in $M M P-1, M M P-13$ and Col2a1 expression levels compared to cells treated with visfatin, resistin or BAY11-7082 alone.

\section{Discussion}

Obesity is considered one of the most important risk factors for OA incidence, progression, and disability [9]. The mechanism by which obesity influences the structural damage of cartilage is not fully elucidated. A potential role was assigned to adipokines [10,34,35]; however, their exact effect on cartilage metabolism have not been completely established and controversial results have been found in chondrocytes [12,36,37].

Along with the well-known role of miRNA in the development and in the progression of OA [24], recent evidence has pointed out the involvement of these factors also in the regulation of adipogenesis, obesity, insulin resistance, and diabetes [38].

According to previous studies, we tested the effects of two different concentrations of visfatin and resistin in chondrocyte cultures focusing on apoptosis, on different miRNA, and on the main factors involved in cartilage metabolism [12,39].

Apoptosis represents a regulated active mechanism of cell death involved in development, homeostasis, and the aging processes, such as OA [40]. Our results demonstrated the pro-apoptotic effect of visfatin and resistin in OA chondrocytes. Gosset et al. [39] did not observe any significant modification in cell viability of OA cells treated with visfatin for $6 \mathrm{~h}$; the discrepancy with our data can be attributed to the shorter timing of visfatin treatment. A more recent study, performed in visfatin-stimulated endothelial cells for $48 \mathrm{~h}$, demonstrated a significant increase of apoptosis and the upregulation of two of the main proteins implicated in the regulation of this process, caspase- 3 and Bax [41], supporting our results. Concerning resistin stimulus, to our knowledge, no studies have been 
performed on chondrocytes cultures; treatment of human breast cancer and myeloma cell lines with resistin reduced the apoptotic cell in a significant dose- and time-dependent manner, resulting in a growth of survival and resistance [42,43]. Our data appear in contrast with the updated literature; however, this could be explained by the experimental procedures differently employed, such as the cellular type analyzed, and the treatment conditions applied.

After the incubation of OA chondrocytes with visfatin and resistin, we demonstrated a significant modulation of a pattern of miRNA implicated in OA pathogenesis, and of some factors involved in cartilage metabolism.

Recent evidence reveals that the increased expression levels of miR-34a caused apoptosis and limited cell proliferation in human OA chondrocytes [44]. Our data reported a significant overexpression of $m i R-34 a$ in visfatin and resistin stimulated cultures. These results are supported by the study of Wen et al. [45], demonstrating the upregulation of miR-34a after the stimulus of HepG2 cells with resistin for $24 \mathrm{~h}$. At the moment, no previous data about the interaction between visfatin and miR-34a are available.

Furthermore, we can hypothesize that the observed negative effects on apoptosis and cell survival by these adipokines are mediated by miR-34a.

A reduced expression of miR-140 has been reported in OA chondrocytes in comparison to normal cells, contributing to regulate the differentiation and proliferation of hypertrophic chondrocytes and the production of some inflammatory cytokine, as well as bone development and cartilage homeostasis [46-48]. Furthermore, some in vitro studies on chondrocytes observed the downregulation of miR-140 induced by pro-inflammatory cytokines [46,47]. Similarly, the stimulus of our OA cultures by visfatin and resistin significantly reduced the expression levels of miR-140.

To our knowledge, no previous data are available and comparable to the results of the present paper; however, a study carried out on ATDC5 chondrocytes cell line demonstrated the regulation of miR-140 after treatment with serum containing leptin [49].

Transfection experiments on animal models and on chondrocyte cultures identified MMP-13 and ADAMTS-5 as direct target genes of miR-140 [50,51].

Metallopreteinase-1 and MMP-13 contribute to promote cartilage breakdown by the degradation of proteoglycans and Col2a1, the main components of the articular extracellular matrix [52,53].

Previous data reported a significant production of $M M P-1$ and $M M P-13$, and a decrease of Col2a1 in OA chondrocytes in comparison to normal cells [12,29,53,54].

In this study we showed an increase of the gene expression of $M M P-1$ and $M M P-13$ and a downregulation of Col2a1 mRNA levels in OA chondrocytes after $24 \mathrm{~h}$ of the stimulus with visfatin and resistin compared to OA non-stimulated cells, highlighting and confirming the involvement of these adipokines in cartilage degradation processes. These data are confirmed by several studies performed on chondrocytes cultures [12,15,39,55-57].

Lately, transfection experiments on human chondrocytes have been performed, showing the negative regulation of $m i R-146 a$ on MMP-13 and ADAMTS-5 levels, indicating the anti-catabolic property of the miRNA [58].

MiRNA-146a is largely expressed in different species and tissues exerting a pivotal role in inflammatory and immune processes and participating in chondrocytes anabolic/catabolic balance [59]; however, data about the pattern of miR-146 expression in OA are controversial $[48,60,61]$. Some in vitro studies demonstrated an opposite modulation of this miRNA after different kinds of stimuli. Indeed, an increase in miR-146a gene expression after the stimulus of OA chondrocytes with IL-1 $\beta$ [61] or after cycles of mechanical injuring pressure [28] was observed, while reduced expression in hydrogen peroxide $\left(\mathrm{H}_{2} \mathrm{O}_{2}\right)$-stimulated chondrocytes was detected [48]. Our results showed, for the first time, a significant decrease in the expression levels of miR-146a in human OA chondrocytes treated with visfatin and a slight, but not significant, reduction after resistin incubation.

Mir-181a and miR-155 have been firstly related to the maturation and the activation of the immune system cells and to the regulation of inflammatory processes in autoimmune diseases and 
in arthritis [62,63]. These miRNA were found increased in the PBMC of OA patients and in human OA chondrocytes compared to normal cells [64-66]. It has been shown that miR-155 and miR-181a are stimulated and consequently activated by pro-inflammatory cytokines such as IL-1 $\beta$ and TNF- $\alpha$ [64] or downregulated by the application of a positive hydrostatic pressure [66]. In a similar manner, in this report, visfatin and resistin stimulus significantly increased the transcriptional levels of miR-181a and miR-155 in OA chondrocyte cultures. In 2013, Sudedi et al. [67] demonstrated that murine RAW 264.7 macrophages incubated with recombinant human globular adiponectin significantly increased the expression levels of miR-155 after $12 \mathrm{~h}$ of stimulus.

Mir-let7e play an important role in cellular proliferation, apoptosis, and inflammation by modulating the NF- $\mathrm{kB}$ signaling [68].

Serum levels of miR-let7 were found inversely correlated with the risk of joint arthroplasty, and this association was independent of age, sex, and BMI, leading to speculate miR-let7e as a potential biomarker for severe OA [69]. Furthermore, miR-let7e represents one of the most prominent miRNA implicated in metabolic syndrome and cardiovascular disorders [70,71].

In this study, we first showed a significant increase of miR-let7e gene expression in OA chondrocyte cultures stimulated with visfatin and resistin suggesting that miR-let7e contributes to explaining the high association between metabolic syndrome, cardiovascular disease, and OA [72,73].

The NF- $\kappa B$ signaling pathway plays a central role in inflammation and in cartilage degradation in OA [74]. In fact, the activated form of NF- $\kappa B$ induces the transcription of various catabolic factors, MMPs, ADAMTS, cytokines and chemokines, pro-inflammatory mediators, and contributes to the degradation of collagen and proteoglycans [74,75]. Different studies showed that visfatin and resistin induce the activation of the NF- $\kappa B$ signaling pathway [41,76-79]. In agreement with the current literature we demonstrated a significant increase of the expression, activation, and in turn of the nuclear translocation of the NF- $\kappa B$ p50 subunit in OA chondrocytes incubated by visfatin and resistin. Moreover, we found a direct interaction between $N F-\kappa B$ and visfatin and resistin stimulus after the inhibition of the NF- $\kappa B$ pathway by using a specific NF- $\kappa B$ inhibitor, BAY11-7082, as described by other authors [12,41,79]. Our data demonstrated that BAY11-7082, downregulating NF- $\kappa B$, reduced the effect of the studied adipokines on MMP-1, MMP-13, and Col2a1 expression. This finding indicates that visfatin, resistin, and BAY11-7082 are effective on chondrocyte metabolism through the regulation of the NF- $\kappa B$ signaling pathway.

In the present study, the effects of visfatin and resistin on the T/C-28a2 cell line were also investigated. We did not observe any significant modification in cell proliferation, apoptosis, as well as in the gene expression of the studied miRNA and Col2a1 on the stimulated cells in comparison to baseline. Visfatin and resistin significantly increased $M M P-1$ and $M M P-13$ levels similarly to the results obtained by Guan et al. [80] on IL-1 $\beta$-stimulated T/C-28a2; the adipokines also increased the gene expression of miR-155 in T/C-28a2 in comparison to un-stimulated cells, while no results from the literature are reported to support this data.

Since there are difficulties and problems related to obtaining healthy human articular cartilage for culture experiments, various chondrocyte cell lines have been developed. Human T/C-28a2 is a line of immortalized cells isolated from human juvenile costal cartilage and is generated by a transfection procedure by using a retroviral vector pZipNeoSV $(X)$ and the SV40 large T antigen. The immortalization of the cells allows the generation of stable lines that express and maintain the differentiated phenotype under defined conditions [81]. They are not the optimal substitution for primary articular chondrocytes, even if, their phenotypic characteristics are close to those of physiologic chondrocytes [82].

$\mathrm{T} / \mathrm{C}-28 \mathrm{a} 2$ cells have been used in some studies to investigate chondrocyte-specific response patterns after stimulation with IL-1 $\beta$ or during loading experiments [83-85]. T/C-28a2-specific responses to cytokines, such as IL- $1 \beta$ or TNF- $\alpha$, or adipokines, as resistin, were similar to those found in human normal chondrocyte cultures [12,81]. 
In our report, the lack of response of $\mathrm{T} / \mathrm{C}-28 \mathrm{a} 2$ to visfatin and resistin stimulus is difficult to explain; one of the possible hypotheses could be a different expression of specific receptors for these adipokines in a cell line with respect to those in OA chondrocytes $[36,86]$.

\section{Materials and Methods}

\subsection{Chondrocyte Cultures}

A human immortalized T/C-28a2 cell line was kindly provided by Goldring Laboratory and derived from human juvenile costal cartilage generated by transfection procedure using a retroviral vector $\mathrm{pZipNeoSV}(\mathrm{X})$ and the SV40 large T antigen as already described [80].

Human OA articular cartilage was obtained from femoral heads of five non-obese (BMI ranging from 20 to $23 \mathrm{Kg} / \mathrm{m}^{2}$ ) and non-diabetic patients (two men and three women, age ranging from 68 to 79 ) with hip OA defined by the clinical and radiological ACR criteria [87], undergoing surgery for total hip replacement. Osteoarthritis grades ranged from moderate to severe, and cartilage showed typical osteoarthritic changes, as the presence of chondrocyte clusters, fibrillation, and loss of metachromasia (Mankin degree 3-7) [88]. Osteoarthritis chondrocytes were derived from the area adjacent to the OA lesion. The femoral heads were supplied by the Orthopaedic Surgery, University of Siena, Italy. The Ethics Committee of the Azienda Ospedaliera Universitaria Senese/Siena University Hospital approved the use of human articular samples (decision no. 726/07), and all subjects signed an informed consent.

The chondrocytes were isolated immediately after surgery. In brief, cartilage fragments were aseptically dissected from each donor and processed by an enzymatic digestion with trypsin (Sigma-Aldrich, Milan, Italy) for $15 \mathrm{~min}$ at $37^{\circ} \mathrm{C}$ and then with type IV collagenase (Sigma-Aldrich, Milan, Italy) for $12-16 \mathrm{~h}$ at $37^{\circ} \mathrm{C}$.

The obtained cell suspension was filtered twice using 70- $\mu$ m nylon meshes, washed, and centrifuged for $5 \mathrm{~min}$ at $700 \times \mathrm{g}$. The viability was assessed by Trypan Blue (Sigma-Aldrich, Milan, Italy) test identifying $90 \%$ to $95 \%$ cell survival. Chondrocytes were recovered, seeded into 10-cm diameter tissue culture plates, and were expanded for 10-12 days in a monolayer incubator with $5 \% \mathrm{CO}_{2}$ and $90 \%$ humidified atmosphere at $37^{\circ} \mathrm{C}$ until it reached $80 \%$ confluence.

Cells were grown in Dulbecco's Modified Eagle Medium (DMEM) (Euroclone, Milan, Italy), containing 10\% Fetal Bovine Serum (FBS) (Euroclone, Milan, Italy), with $200 \mathrm{U} / \mathrm{mL}$ penicillin and $200 \mu \mathrm{g} / \mathrm{mL}$ streptomycin (P/S) (Sigma-Aldrich, Milan, Italy). The medium was changed every 3-4 days. The cell morphology was examined daily with an inverted microscope (Olympus IMT-2, Tokyo, Japan), and OA primary chondrocytes at the first passage were employed for the experiments to guarantee their phenotypic stability preserved which can occur when subcultured in monolayer [36]. For each single experiment a cell culture from a unique donor was used.

\subsection{Treatment of Chondrocyte Cultures}

$\mathrm{T} / \mathrm{C}-28 \mathrm{a} 2$ cell line and human OA chondrocytes, at the first passage, were plated in 6-well dishes at a starting density of $6 \times 10^{6}$ cells/well until they became confluent. Human recombinant visfatin (Sigma-Aldrich, Milan, Italy) and human recombinant resistin (BioVendor, Rome, Italy) were first dissolved in phosphate buffered saline (PBS) (Euroclone, Milan, Italy), according to the manufacturer's instructions, and then they were diluted in the culture medium immediately before the treatment to reach the final concentration required.

The cells were treated for $24 \mathrm{~h}$ with visfatin at concentration of $5 \mu \mathrm{g} / \mathrm{mL}$ and $10 \mu \mathrm{g} / \mathrm{mL}$ or resistin $50 \mathrm{ng} / \mathrm{mL}$ and $100 \mathrm{ng} / \mathrm{mL}$. The concentrations of the adipokines used in our in vitro study were selected according to those used by other authors [12,39]; the final concentrations were chosen based on the best results obtained in terms of viability. 
After the treatment, the media were removed, centrifuged, and stored at $-80^{\circ} \mathrm{C}$; the cells were immediately processed to carry out cell viability assay, flow cytometry analysis, and quantitative real-time PCR.

Afterwards, the cells were pre-incubated for $2 \mathrm{~h}$ with $1 \mu \mathrm{M}$ BAY 11-7082 (NF- $\kappa B$ inhibitor, IKK $\alpha / \beta$, Sigma-Aldrich, Milan, Italy) and then treated $24 \mathrm{~h}$ with the tested concentrations of visfatin and resistin. Subsequently, the gene expression of MMP-1, MMP-13, and Col2a1 was evaluated.

\subsection{MTT Assay}

The viability of the cells was evaluated immediately after the treatment by MTT assay. Chondrocytes were incubated for $3 \mathrm{~h}$ at $37{ }^{\circ} \mathrm{C}$ in a culture medium containing $10 \%$ of $5 \mathrm{mg} / \mathrm{mL}$ MTT (3-[4,4-dimethylthiazol-2-yl]-2,5-diphenyl-tetrazoliumbromide) (Sigma-Aldrich, Milan, Italy). After the period of incubation, the medium was removed and $0.2 \mathrm{~mL}$ of dimethyl sulfoxide (DMSO) (Rottapharm Biotech, Monza, Italy) was added to each well to solubilize the formazan crystals. The absorbance was measured at $570 \mathrm{~nm}$ in a microplate reader (BioTek Instruments, Inc., Winooski, VT, USA). A control well without cells was employed for blank measurement.

The percentage of survival cells was evaluated:

$$
\% \text { of survival cells }=(\text { absorbance of considered sample }) /(\text { absorbance of control }) \times 100
$$

The experiments were performed on pre-confluent cell cultures in order to prevent contact inhibition which can condition the results. Data were reported as OD units per $10^{4}$ adherent cells.

\subsection{Detection of Apoptosis}

The evaluation of apoptotic cells was developed by using Annexin V-FITC and propidium iodide (PI) (ThermoFisher Scientific, Milan, Italy). T/C-28a2 cell line and OA chondrocyte were seeded in 12 -well plates $\left(8 \times 10^{4}\right.$ cells/well) for $24 \mathrm{~h}$ in DMEM with $10 \% \mathrm{FBS}$. Then, the medium was removed, and the cells were cultured in DMEM with $0.5 \%$ FBS usually used during the treatment procedure. After that, the chondrocytes were washed and harvested by using trypsin, collected into cytometry tubes, and centrifuged at $1500 \mathrm{rpm}$ for $10 \mathrm{~min}$. The supernatant was replaced, and the pellet was resuspended in $100 \mu \mathrm{L}$ of $1 \times$ Annexin-binding buffer, $5 \mu \mathrm{L}$ of Alexa Fluor 488 annexin-V conjugated to fluorescein (green fluorescence) and $1 \mu \mathrm{L}$ of $100 \mu \mathrm{g} / \mathrm{mL}$ propidium iodide working solution. They were added to $100 \mu \mathrm{L}$ of cell suspension. Cells were incubated at room temperature for $15 \mathrm{~min}$ in the dark. Then, $600 \mu \mathrm{L}$ of $1 \times$ Annexin-binding buffer was added before the analysis at flow cytometer. A total of 10,000 events $\left(1 \times 10^{4}\right.$ cells per assay) were measured by the instrument. The obtained results were analyzed with Cell Quest software (Version 4.0, Becton Dickinson, San Jose, CA, USA). The evaluation of apoptosis was carried out considering staining cells simultaneously with Alexa Fluor 488 annexin- $V$ and propidium iodide; this allowed to discriminate intact cells (annexin- $V$ and propidium iodide-negative), early apoptosis (annexin-V-positive and propidium iodide-negative), and late apoptosis (annexin- $\mathrm{V}$ and propidium iodide positives) [85].

The results were expressed as a percentage of positive cells to each dye (total apoptosis), and the data were represented as the mean of three independent experiments (mean \pm standard deviation (SD).

\subsection{RNA Isolation and Quantitative Real-Time PCR}

Total RNA, including miRNA, was extracted using TriPure Isolation Reagent (Euroclone, Milan, Italy) according to the manufacturer's instructions, and was stored at $-80^{\circ} \mathrm{C}$. The concentration, purity, and integrity of RNA were evaluated by measuring the OD at $260 \mathrm{~nm}$ and the $260 / 280$ and 260/230 ratios by Nanodrop-1000 (Celbio, Milan, Italy). The quality of RNA was verified by electrophoresis on agarose gel (FlashGel System, Lonza, Rockland, ME, USA). Reverse transcription for miRNA was carried out by the cDNA miScript PCR Reverse Transcription (Qiagen, Hilden, Germany), 
while the same procedure for target genes by QuantiTect Reverse Transcription Kit (Qiagen, Germany), according to the manufacturer's instructions.

miRNA and target genes were examined by real-time PCR using, miScript SYBR Green (Qiagen, Hilden, Germany) and QuantiFast SYBR Green PCR (Qiagen, Hilden, Germany) kits, respectively. A list of the used primers is reported in Table 1. All qPCR reactions were achieved in glass capillaries by a LightCycler 1.0 (Roche Molecular Biochemicals, Mannheim, Germany) with LightCycler Software Version 3.5. The reaction procedure miRNA consisted $95{ }^{\circ} \mathrm{C}$ for $15 \mathrm{~min}$ for HotStart polymerase activation, followed by 40 cycles of $15 \mathrm{~s}$ at $95{ }^{\circ} \mathrm{C}$ for denaturation, $30 \mathrm{~s}$ at $55{ }^{\circ} \mathrm{C}$ for annealing, and $30 \mathrm{~s}$ at $70{ }^{\circ} \mathrm{C}$ for elongation, according to the protocol. Target gene amplification was performed at 5 in at $95^{\circ} \mathrm{C}, 40$ cycles of $15 \mathrm{~s}$ at $95^{\circ} \mathrm{C}$, and $30 \mathrm{~s}$ at $60^{\circ} \mathrm{C}$. In the final step of both protocols, the temperature was raised from $60^{\circ} \mathrm{C}$ to $95^{\circ} \mathrm{C}$ at $0.1^{\circ} \mathrm{C} /$ step to plot the melting curve.

Table 1. Primers used for RT-qPCR.

\begin{tabular}{cc}
\hline miRNA Gene & Cat. No. (Qiagen) \\
\hline$m i R-34 a$ & MS00003318 \\
miR-140 & MS00003500 \\
miR-146a & MS00003535 \\
$m i R-155$ & MS00008778 \\
miR-181a & MS00006692 \\
miR-let7e & MS00031801 \\
\hline Target Gene & Cat. No. (Qiagen) \\
\hline MMP-1 & QT00014581 \\
MMP-13 & QT00001764 \\
Col2a1 & QT00049518 \\
\hline
\end{tabular}

To further analyze the dissociation curves, we visualized the amplicons lengths in an agarose gel to confirm the correct amplification of the resulting PCR products.

For the data analysis, the $C_{t}$ values of each sample and the efficiency of the primer set were calculated through LinReg Software [89] and then converted into relative quantities and normalized using the Pfaffl model [90].

The normalization was performed considering SNORD-25 for miRNA and HPRT-1 for target genes, as the housekeeping genes. These genes were chosen according to geNorm software version 3.5 [91].

\subsection{Immunofluorescence}

Osteoarthritis chondrocytes at the first passage were plated in coverslips in Petri dishes $(35 \times 10 \mathrm{~mm})$ at a starting low density of $4 \times 10^{4}$ cells/chamber, to prevent possible cell overlapping, and re-suspended in $2 \mathrm{~mL}$ of culture medium until $80 \%$ of confluence. The cells were processed after $2 \mathrm{~h}$ of treatment with adipokines to evaluate the potential activation of the NF- $\kappa B$ pathway. The chondrocytes were washed in phosphate-buffered saline (PBS) (Euroclone, Milan, Italy) and then fixed in methanol for $15 \mathrm{~min}$ and in acetone for $5 \mathrm{~min}$ at $-20{ }^{\circ} \mathrm{C}$. Afterwards, the cells were permeabilized with a blocking solution (PBS and $2 \%$ bovine serum albumin (BSA) (Sigma-Aldrich, Milan, Italy) for $20 \mathrm{~min}$ at room temperature, and then incubated overnight at $4{ }^{\circ} \mathrm{C}$ with mouse monoclonal anti-p50 subunit primary antibody (Santa Cruz Biotechnology, Italy) diluted at 1:50 in PBS and $0.1 \%$ BSA. Three washes in PBS of the coverslips were followed by $1 \mathrm{hr}$ incubation with goat anti-mouse IgG-Texas Red conjugated antibody (Southern Biotechnology, Italy) diluted at 1:100 in PBS and 0.1\% BSA. Finally, the coverslips were mounted with Vecta shield (Vector Labs). Fluorescence was examined under an AxioPlan (Zeiss, Oberkochen, Germany) light microscope equipped with epifluorescence at $200 \times$ and $400 \times$ magnification. The negative controls were obtained by omitting the primary antibody. Immunoreactivity of p50 was semi-quantified as the mean 
densitometric area of p50 signal into the nucleus and into the cytoplasm, by AxioVision 4.6 software measure program [92]. At least $100 \mathrm{OA}$ chondrocytes from each group were evaluated.

\subsection{Statistical Analysis}

Three independent experiments were carried out and the results were expressed as the mean \pm SD of triplicate values for each experiment. Data normal distribution was evaluated by Shapiro-Wilk, D'Agostino and Pearson, and Kolmogorov-Smirnov tests.

Data from real-time PCR were evaluated by one-way ANOVA with a Tukey's post-hoc test using $2^{-\Delta \Delta \mathrm{CT}}$ values for each sample.

All analyses were performed through the SAS System (SAS Institute Inc., Cary, NC, USA) and GraphPad Prism 6.1. A significant value was defined with a $p$-value $<0.05$.

\section{Conclusions}

Our data demonstrate for the first time the effect of visfatin and resistin in modulating the expression levels of some miRNA normally aberrantly expressed in OA. Moreover, the results show a significant decrease at transcriptional levels of the main proteases involved in OA pathogenesis inducing to speculate about the role of adipokines in cartilage degradation. The observed transcriptional modifications of miRNA and target genes seem to be due to the modulation of the NF-kB signaling pathway.

However, our report presents some limitations that have to be noticed. The results of the current study are limited to the lack of the same evaluation performed on normal primary chondrocytes. Moreover, additional experiments to better elucidate the direct relationship between visfatin, resistin, and the NF- $\kappa B$ signaling pathway modulation are required; for instance, transfection experiments with anti-miRNA could be useful in identifying the regulation of specific target genes, useful to elucidate their mechanism of action.

Taken together, these results confirm the complex relationship between adipokines and miRNA and contribute to explain the role of obesity in the pathogenesis of OA and the relevance of weight loss, confirming the importance of controlling body weight in the treatment of the disease.

Author Contributions: The authors declare to have participated in the drafting of this paper as specified below: S.C.: performed cell cultures, cell treatment, qRT-PCR, flow cytometry, immunofluorescence, data analysis, contributed to write protocol and article; N.G.: contributed to writing the protocol and the article; N.V.: performed immunofluorescence analysis and contributedd to writing the article; S.T.: contributed to writing the article; I.G.: performed cell cultures, cell treatment, flow cytometry, immunofluorescence, data analysis, and qRT-PCR; M.D.M.: carried out the surgery of femoral heads; S.G.: carried out the surgery of femoral heads and contributed to writing the article; A.F.: contributed to writing the protocol and the article.

Funding: This research received no external funding.

Acknowledgments: This research did not receive any specific grant from funding agencies in the public, commercial, or not-for-profit sectors.

Conflicts of Interest: The authors affirm that there are no conflicts of interest.

\section{References}

1. Vos, T.; Allen, C.; Arora, M.; Barber, R.M.; Bhutta, Z.A.; Brown, A.; Carter, A.; Casey, D.C.; Charlson, F.J.; Chen, A.Z.; et al. Global, regional, and national incidence, prevalence, and years lived with disability for 310 diseases and injuries, 1990-2015: A systematic analysis for the Global Burden of Disease Study 2015. Lancet 2016, 388, 1545-1602. [CrossRef]

2. Loeser, R.F.; Goldring, S.R.; Scanzello, C.R.; Goldring, M.B. Osteoarthritis: A disease of the joint as an organ. Arthritis Rheum. 2012, 64, 1697-1707. [CrossRef]

3. Goldring, M.B.; Goldring, S.R. Articular cartilage and subchondral bone in the pathogenesis of osteoarthritis. Ann. N. Y. Acad. Sci. 2010, 1192, 230-237. [CrossRef] [PubMed] 
4. Robinson, W.H.; Lepus, C.M.; Wang, Q.; Raghu, H.; Mao, R.; Lindstrom, T.M.; Sokolove, J. Low-grade inflammation as a key mediator of the pathogenesis of osteoarthritis. Nat. Rev. Rheumatol. 2016, 12, 580-592. [CrossRef] [PubMed]

5. Mobasheri, A.; Rayman, M.P.; Gualillo, O.; Sellam, J.; van der Kraan, P.; Fearon, U. The role of metabolism in the pathogenesis of osteoarthritis. Nat. Rev. Rheumatol. 2017, 13, 302-311. [CrossRef]

6. Reyes, C.; Leyland, K.M.; Peat, G.; Cooper, C.; Arden, N.K.; Prieto-Alhambra, D. Association Between Overweight and Obesity and Risk of Clinically Diagnosed Knee, Hip, and Hand Osteoarthritis: A Population-Based Cohort Study. Arthritis Rheumatol. 2016, 68, 1869-1875. [CrossRef]

7. Ng, M.; Fleming, T.; Robinson, M.; Thomson, B.; Graetz, N.; Margono, C.; Mullany, E.; Biryukov, S.; Abbafati, C.; Abera, S.F.; et al. Global, regional, and national prevalence of overweight and obesity in children and adults during 1980-2013: A systematic analysis for the Global Burden of Disease Study 2013. Lancet 2014, 384, 766-781. [CrossRef]

8. Yusuf, E. Metabolic factors in osteoarthritis: obese people do not walk on their hands. Arthritis Res. Ther. 2012, 14, 123. [CrossRef] [PubMed]

9. Berenbaum, F.; Eymard, F.; Houard, X. Osteoarthritis, inflammation and obesity. Curr. Opin. Rheumatol. 2013, 25, 114-118. [CrossRef]

10. Neumann, E.; Junker, S.; Schett, G.; Frommer, K.; Müller-Ladner, U. Adipokines in bone disease. Nat. Rev. Rheumatol. 2016, 12, 296-302. [CrossRef]

11. Poonpet, T.; Honsawek, S. Adipokines: Biomarkers for osteoarthritis? World J. Orthop. 2014, 5, 319-327. [CrossRef] [PubMed]

12. Zhang, Z.; Xing, X.; Hensley, G.; Chang, L.W.; Liao, W.; Abu-Amer, Y.; Sandell, L.J. Resistin induces expression of proinflammatory cytokines and chemokines in human articular chondrocytes via transcription and messenger RNA stabilization. Arthritis Rheum. 2010, 62, 1993-2003. [CrossRef] [PubMed]

13. Choe, J.Y.; Bae, J.; Jung, H.Y.; Park, S.H.; Lee, H.J.; Kim, S.K. Serum resistin level is associated with radiographic changes in hand osteoarthritis: Cross-sectional study. Joint Bone Spine. 2012, 79, 160-165. [CrossRef]

14. Fioravanti, A.; Cheleschi, S.; De Palma, A.; Addimanda, O.; Mancarella, L.; Pignotti, E.; Pulsatelli, L.; Galeazzi, M.; Meliconi, R. Can adipokines serum levels be used as biomarkers of hand osteoarthritis? Biomarkers 2018, 23, 265-270. [CrossRef] [PubMed]

15. Koskinen, A.; Vuolteenaho, K.; Moilanen, T.; Moilanen, E. Resistin as a factor in osteoarthritis: Synovial fluid resistin concentrations correlate positively with interleukin 6 and matrix metalloproteinases MMP-1 and MMP-3. Scand. J. Rheumatol. 2014, 43, 249-253. [CrossRef] [PubMed]

16. Calvet, J.; Orellana, C.; Gratacós, J.; Berenguer-Llergo, A.; Caixàs, A.; Chillarón, J.J.; Pedro-Botet, J.; García-Manrique, M.; Navarro, N.; Larrosa, M. Synovial fluid adipokines are associated with clinical severity in knee osteoarthritis: A cross-sectional study in female patients with joint effusion. Arthritis Res. Ther. 2016, 18, 207. [CrossRef] [PubMed]

17. Richter, M.; Trzeciak, T.; Rybka, J.D.; Suchorska, W.; Augustyniak, E.; Lach, M.; Kaczmarek, M.; Kaczmarczyk, J. Correlations between serum adipocytokine concentrations, disease stage, radiological status and total body fat content in the patients with primary knee osteoarthritis. Int. Orthop. 2017, 41, 983-989. [CrossRef]

18. Laiguillon, M.C.; Houard, X.; Bougault, C.; Gosset, M.; Nourissat, G.; Sautet, A.; Jacques, C.; Berenbaum, F.; Sellam, J. Expression and function of visfatin (Nampt), an adipokine-enzyme involved in inflammatory pathways of osteoarthritis. Arthritis Res. Ther. 2014, 16, R38. [CrossRef]

19. Sun, Z.; Lei, H.; Zhang, Z. Pre-B cell colony enhancing factor (PBEF), a cytokine with multiple physiological functions. Cytokine Growth Factor Rev. 2013, 24, 433-442. [CrossRef]

20. Wu, M.H.; Tsai, C.H.; Huang, Y.L.; Fong, Y.C.; Tang, C.H. Visfatin Promotes IL-6 and TNF- $\alpha$ Production in Human Synovial Fibroblasts by Repressing miR-199a-5p through ERK, p38 and JNK Signaling Pathways. Int. J. Mol. Sci. 2018, 19, 190. [CrossRef]

21. Liao, L.; Chen, Y.; Wang, W. The current progress in understanding the molecular functions and mechanisms of visfatin in osteoarthritis. J. Bone. Miner. Metab. 2016, 34, 485-490. [CrossRef] [PubMed]

22. Tenti, S.; Palmitesta, P.; Giordano, N.; Galeazzi, M.; Fioravanti, A. Increased serum leptin and visfatin levels in patients with diffuse idiopathic skeletal hyperostosis: a comparative study. Scand. J. Rheumatol. 2017, 46, 156-158. [CrossRef] [PubMed] 
23. Wu, L.; Belasco, J.G. Let me count the ways: Mechanisms of gene regulation by miRNAs and siRNAs. Mol. Cell. 2008, 29, 1-7. [CrossRef] [PubMed]

24. De Palma, A.; Cheleschi, S.; Pascarelli, N.A.; Tenti, S.; Galeazzi, M.; Fioravanti, A. Do microRNAs have a key epigenetic role in osteoarthritis and in mechanotransduction? Clin. Exp. Rheumatol. 2017, 35, 518-526. [PubMed]

25. Cong, L.; Zhu, Y.; Tu, G. A bioinformatic analysis of microRNAs role in osteoarthritis. Osteoarthritis Cartilage. 2017, 25, 1362-1371. [CrossRef] [PubMed]

26. Malemud, C.J. MicroRNAs and Osteoarthritis. Cells 2018, 7, 92. [CrossRef] [PubMed]

27. Díaz-Prado, S.; Cicione, C.; Muiños-López, E.; Hermida-Gómez, T.; Oreiro, N.; Fernández-López, C.; Blanco, F.J. Characterization of microRNA expression profiles in normal and osteoarthritic human chondrocytes. BMC Musculoskelet. Disord. 2012, 13, 144. [CrossRef]

28. Jin, L.; Zhao, J.; Jing, W.; Yan, S.; Wang, X.; Xiao, C.; Ma, B. Role of miR-146a in human chondrocyte apoptosis in response to mechanical pressure injury in vitro. Int. J. Mol. Med. 2014, 34, 451-463. [CrossRef]

29. Cheleschi, S.; De Palma, A.; Pecorelli, A.; Pascarelli, N.A.; Valacchi, G.; Belmonte, G.; Carta, S.; Galeazzi, M.; Fioravanti, A. Hydrostatic Pressure Regulates MicroRNA Expression Levels in Osteoarthritic Chondrocyte Cultures via the Wnt/ $\beta$-Catenin Pathway. Int. J. Mol. Sci. 2017, 18, 133. [CrossRef]

30. Jones, S.W.; Watkins, G.; Le Good, N.; Roberts, S.; Murphy, C.L.; Brockbank, S.M.; Needham, M.R.; Read, S.J.; Newham, P. The identification of differentially expressed microRNA in osteoarthritic tissue that modulate the production of TNF- $\alpha$ and MMP13. Osteoarthritis Cartilage. 2009, 17, 464-472. [CrossRef]

31. Prasadam, I.; Batra, J.; Perry, S.; Gu, W.; Crawford, R.; Xiao, Y. Systematic identification, characterization and target gene analysis of microRNAs involved in osteoarthritis subchondral bone pathogenesis. Calcif. Tissue Int. 2016, 99, 43-55. [CrossRef] [PubMed]

32. Gerin, I.; Bommer, G.T.; McCoin, C.S.; Sousa, K.M.; Krishnan, V.; MacDougald, O.A. Roles for miRNA-378/378* in adipocyte gene expression and lipogenesis. Am. J. Physiol. Endocrinol. Metab. 2010, 299, 198-206. [CrossRef] [PubMed]

33. Maurizi, G.; Babini, L.; Della Guardia, L. Potential role of microRNAs in the regulation of adipocytes liposecretion and adipose tissue physiology. J. Cell. Physiol. 2018, 17, 19-26. [CrossRef] [PubMed]

34. Azamar-Llamas, D.; Hernández-Molina, G.; Ramos-Ávalos, B.; Furuzawa-Carballeda, J. Adipokine Contribution to the Pathogenesis of Osteoarthritis. Mediat. Inflamm. 2017, 2017, 5468023. [CrossRef] [PubMed]

35. Junker, S.; Frommer, K.W.; Krumbholz, G.; Tsiklauri, L.; Gerstberger, R.; Rehart, S.; Steinmeyer, J.; Rickert, M.; Wenisch, S.; Schett, G.; Müller-Ladner, U.; Neumann, E. Expression of adipokines in osteoarthritis osteophytes and their effect on osteoblasts. Matrix Biol. 2017, 62, 75-91. [CrossRef] [PubMed]

36. Francin, P.J.; Guillaume, C.; Humbert, A.C.; Pottie, P.; Netter, P.; Mainard, D.; Presle, N. Association between the chondrocyte phenotype and the expression of adipokines and their receptors: evidence for a role of leptin but not adiponectin in the expression of cartilage-specific markers. J. Cell. Physiol. 2011, 226, 2790-2797. [CrossRef]

37. Francin, P.J.; Abot, A.; Guillaume, C.; Moulin, D.; Bianchi, A.; Gegout-Pottie, P.; Jouzeau, J.Y.; Mainard, D.; Presle, N. Association between adiponectin and cartilage degradation in human osteoarthritis. Osteoarthritis Cartilage 2014, 22, 519-526. [CrossRef]

38. Deiuliis, J.A. MicroRNAs as regulators of metabolic disease: pathophysiologic significance and emerging role as biomarkers and therapeutics. Int J. Obes. (Lond) 2016, 40, 88-101. [CrossRef]

39. Gosset, M.; Berenbaum, F.; Salvat, C.; Sautet, A.; Pigenet, A.; Tahiri, K.; Jacques, C. Crucial role of visfatin/pre-B cell colony-enhancing factor in matrix degradation and prostaglandin E2 synthesis in chondrocytes: Possible influence on osteoarthritis. Arthritis Rheum. 2008, 58, 1399-1409. [CrossRef]

40. Hwang, H.S.; Kim, H.A. Chondrocyte Apoptosis in the Pathogenesis of Osteoarthritis. Int. J. Mol. Sci. 2015, 16, 26035-26054. [CrossRef]

41. Sun, L.; Chen, S.; Gao, H.; Ren, L.; Song, G. Visfatin induces the apoptosis of endothelial progenitor cells via the induction of pro-inflammatory mediators through the NF-kB pathway. Int. J. Mol. Med. 2017, 40, 637-646. [CrossRef] [PubMed]

42. Liu, Z.; Shi, A.; Song, D.; Han, B.; Zhang, Z.; Ma, L.; Liu, D.; Fan, Z. Resistin confers resistance to doxorubicin-induced apoptosis in human breast cancer cells through autophagy induction. Am. J. Cancer Res. 2017, 7, 574-583. [PubMed] 
43. Pang, J.; Shi, Q.; Liu, Z.; He, J.; Liu, H.; Lin, P.; Cui, J.; Yang, J. Resistin induces multidrug resistance in myeloma by inhibiting cell death and upregulating ABC transporter expression. Haematologica 2017, 102, 1273-1280. [CrossRef]

44. Yan, S.; Wang, M.; Zhao, J.; Zhang, H.; Zhou, C.; Jin, L.; Zhang, Y.; Qiu, X.; Ma, B.; Fan, Q. MicroRNA-34a affects chondrocyte apoptosis and proliferation by targeting the SIRT1/p53 signaling pathway during the pathogenesis of osteoarthritis. Int. J. Mol. Med. 2016, 38, 201-209. [CrossRef] [PubMed]

45. Wen, F.; Li, B.; Huang, C.; Wei, Z.; Zhou, Y.; Liu, J.; Zhang, H. MiR-34a is Involved in the Decrease of ATP Contents Induced by Resistin Through Target on ATP5S in HepG2 Cells. Biochem. Genet. 2015, 53, 301-309. [CrossRef] [PubMed]

46. Miyaki, S.; Nakasa, T.; Otsuki, S.; Grogan, S.P.; Higashiyama, R.; Inoue, A.; Kato, Y.; Sato, T.; Lotz, M.K.; Asahara, H. MicroRNA-140 is expressed in differentiated human articular chondrocytes and modulates interleukin-1 responses. Arthritis Rheum. 2009, 60, 2723-2730. [CrossRef] [PubMed]

47. Miyaki, S.; Sato, T.; Inoue, A.; Otsuki, S.; Ito, S.Y.; Yokoyama, S.; Kato, Y.; Takemoto, F.; Nakasa, T.; Yamashita, S.; et al. MicroRNA-140 plays dual roles in both cartilage development and homeostasis. Genes Dev. 2010, 24, 1173-1185. [CrossRef]

48. Cheleschi, S.; De Palma, A.; Pascarelli, N.A.; Giordano, N.; Galeazzi, M.; Tenti, S.; Fioravanti, A. Could Oxidative Stress Regulate the Expression of MicroRNA-146a and MicroRNA-34a in Human Osteoarthritic Chondrocyte Cultures? Int. J. Mol Sci. 2017, 18, 2660. [CrossRef]

49. Pando, R.; Shtaif, B.; Phillip, M.; Gat-Yablonski, G. A serum component mediates food restriction-induced growth attenuation. Endocrinology 2014, 155, 932-940. [CrossRef]

50. Tardif, G.; Hum, D.; Pelletier, J.P.; Duval, N.; Martel-Pelletier, J. Regulation of the IGFBP-5 and MMP-13 genes by the microRNAs miR-140 and miR-27a in human osteoarthritic chondrocytes. BMC Musculoskelet. Disord. 2009, 10, 148. [CrossRef]

51. Akhtar, N.; Rasheed, Z.; Ramamurthy, S.; Anbazhagan, A.N.; Voss, F.R.; Haqqi, T.M. MicroRNA-27b regulates the expression of matrix metalloproteinase 13 in human osteoarthritis chondrocytes. Arthritis Rheum. 2010, 62, 1361-1371. [CrossRef] [PubMed]

52. Cawston, T.E.; Young, D.A. Proteinases involved in matrix turnover during cartilage and bone breakdown. Cell. Tissue. Res. 2010, 339, 221-235. [CrossRef] [PubMed]

53. Troeberg, L.; Nagase, H. Proteases involved in cartilage matrix degradation in osteoarthritis. Biochim. Biophys. Acta. 2012, 1824, 133-145. [CrossRef] [PubMed]

54. Goldring, M.B.; Otero, M.; Plumb, D.A.; Dragomir, C.; Favero, M.; El Hachem, K.; Hashimoto, K.; Roach, H.I.; Olivotto, E.; Borzì, R.M.; Marcu, K.B. Roles of inflammatory and anabolic cytokines in cartilage metabolism: Signals and multiple effectors converge upon MMP-13 regulation in osteoarthritis. Eur. Cell. Mater. 2011, 21, 202-220. [CrossRef] [PubMed]

55. Christgau, S.; Garnero, P.; Fledelius, C.; Moniz, C.; Ensig, M.; Gineyts, E.; Rosenquist, C.; Qvist, P. Collagen type II C-telopeptide fragments as an index of cartilage degradation. Bone 2001, 29, 209-215. [CrossRef]

56. Lee, J.H.; Ort, T.; Ma, K.; Picha, K.; Carton, J.; Marsters, P.A.; Lohmander, L.S.; Baribaud, F.; Song, X.Y.; Blake, S. Resistin is elevated following traumatic joint injury and causes matrix degradation and release of inflammatory cytokines from articular cartilage in vitro. Osteoarthritis Cartilage 2009, 17, 613-620. [CrossRef] [PubMed]

57. Yang, S.; Ryu, J.H.; Oh, H.; Jeon, J.; Kwak, J.S.; Kim, J.H.; Kim, H.A.; Chun, C.H.; Chun, J.S. NAMPT (visfatin), a direct target of hypoxia-inducible factor- $2 \alpha$, is an essential catabolic regulator of osteoarthritis. Ann. Rheum. Dis. 2015, 74, 595-602. [CrossRef]

58. Li, X.; Gibson, G.; Kim, J.S.; Kroin, J.; Xu, S.; van Wijnen, A.J.; Im, H.J. MicroRNA-146a is linked to pain-related pathophysiology of osteoarthritis. Gene 2011, 480, 34-41. [CrossRef]

59. Li, L.; Chen, X.P.; Li, Y.J. MicroRNA-146a and human disease. Scand. J. Immunol. 2010, 71, 227-231. [CrossRef]

60. Yamasaki, K.; Nakasa, T.; Miyaki, S.; Ishikawa, M.; Deie, M.; Adachi, N.; Yasunaga, Y.; Asahara, H.; Ochi, M. Expression of MicroRNA-146a in osteoarthritis cartilage. Arthritis Rheum. 2009, 60, 1035-1041. [CrossRef]

61. Li, J.; Huang, J.; Dai, L.; Yu, D.; Chen, Q.; Zhang, X.; Dai, K. miR-146a, an IL-1 $\beta$ responsive miRNA, induces vascular endothelial growth factor and chondrocyte apoptosis by targeting Smad4. Arthritis Res. Ther. 2012, 14, R75. [CrossRef] [PubMed] 
62. Chen, C.Z.; Li, L.; Lodish, H.F.; Bartel, D.P. MicroRNAs modulate hematopoietic lineage differentiation. Science 2004, 303, 83-86. [CrossRef] [PubMed]

63. Kurowska-Stolarska, M.; Alivernini, S.; Ballantine, L.E.; Asquith, D.L.; Millar, N.L.; Gilchrist, D.S.; Reilly, J.; Ierna, M.; Fraser, A.R.; Stolarski, B.; et al. MicroRNA-155 as a proinflammatory regulator in clinical and experimental arthritis. Proc. Natl. Acad. Sci. USA. 2011, 108, 11193-11198. [CrossRef] [PubMed]

64. Okuhara, A.; Nakasa, T.; Shibuya, H.; Niimoto, T.; Adachi, N.; Deie, M.; Ochi, M. Changes in microRNA expression in peripheral mononuclear cells according to the progression of osteoarthritis. Mod. Rheumatol. 2012, 22, 446-457. [CrossRef] [PubMed]

65. Fisch, K.M.; Akagi, R.; Alvarez-Garcia, O.; Teramura, T.; Muramatsu, Y.; Saito, M.; Duffy, S.; Grogan, S.; Sasho, T.; D'Lima, D.; et al. Integrative omics profiling reveals dysregulated novel pathways mediated by microRNAs and DNA methylation in osteoarthritis. Arthritis Rheumatol. 2014, 66, S829-S830.

66. De Palma, A.; Cheleschi, S.; Pascarelli, N.A.; Giannotti, S.; Galeazzi, M.; Fioravanti, A. Hydrostatic pressure as epigenetic modulator in chondrocyte cultures: A. study on miRNA-155, miRNA-181a and miRNA-223 expression levels. J. Biomech. 2018, 66, 165-169. [CrossRef] [PubMed]

67. Subedi, A.; Park, P.H. Autocrine and paracrine modulation of microRNA-155 expression by globular adiponectin in RAW 264.7 macrophages: involvement of MAPK/NF-kB pathway. Cytokine 2013, 64, 638-641. [CrossRef] [PubMed]

68. Zhang, W.; Chen, X.; Qin, Z. MicroRNA let-7a suppresses the growth and invasion of cholesteatoma keratinocytes. Mol. Med. Rep. 2015, 11, 2097-2103. [CrossRef] [PubMed]

69. Beyer, C.; Zampetaki, A.; Lin, N.Y.; Kleyer, A.; Perricone, C.; Iagnocco, A.; Distler, A.; Langley, S.R.; Gelse, K.; Sesselmann, S.; et al. Signature of circulating microRNAs in osteoarthritis. Ann. Rheum. Dis. 2015, 74, e18. [CrossRef] [PubMed]

70. Krause, B.J.; Carrasco-Wong, I.; Dominguez, A.; Arnaiz, P.; Farías, M.; Barja, S.; Mardones, F.; Casanello, P. Micro-RNAs Let7e and 126 in Plasma as Markers of Metabolic Dysfunction in 10 to 12 Years Old Children. PLoS ONE 2015, 10, e0128140. [CrossRef] [PubMed]

71. Bao, M.H.; Feng, X.; Zhang, Y.W.; Lou, X.Y.; Cheng, Y.; Zhou, H.H. Let-7 in cardiovascular diseases, heart development and cardiovascular differentiation from stem cells. Int. J. Mol. Sci. 2013, 14, 23086-23102. [CrossRef] [PubMed]

72. Zhuo, Q.; Yang, W.; Chen, J.; Wang, Y. Metabolic syndrome meets osteoarthritis. Nat. Rev. Rheumatol. 2012, 8, 729-737. [CrossRef] [PubMed]

73. Li, S.; Felson, D.T. What is the evidence to support the association between metabolic syndrome and osteoarthritis?-A systematic review. Arthritis Care Res. (Hoboken) 2018. [Epub ahead of print]. [CrossRef] [PubMed]

74. Rigoglou, S.; Papavassiliou, A.G. The NF-kB signaling pathway in osteoarthritis. Int. J. Biochem. Cell. Biol. 2013, 45, 2580-2584. [CrossRef] [PubMed]

75. Zhang, Q.; Lenardo, M.J.; Baltimore, D. 30 Years of NF-kB: A blossoming of relevance to human pathobiology. Cell 2017, 168, 37-57. [CrossRef]

76. Romacho, T.; Azcutia, V.; Vázquez-Bella, M.; Matesanz, N.; Cercas, E.; Nevado, J.; Carraro, R.; Rodríguez-Mañas, L.; Sánchez-Ferrer, C.F.; Peiró, C. Extracellular PBEF/NAMPT/visfatin activates pro-inflammatory signalling in human vascular smooth muscle cells through nicotinamide phosphoribosyltransferase activity. Diabetologia 2009, 52, 2455-2463. [CrossRef] [PubMed]

77. Aslani, M.R.; Keyhanmanesh, R.; Alipour, M.R. Increased Visfatin Expression Is Associated with Nuclear Factor-kB in Obese Ovalbumin-Sensitized Male Wistar Rat Tracheae. Med. Princ. Pract. 2017, 26, 351-358. [CrossRef] [PubMed]

78. Zhang, Z.; Zhang, Z.; Kang, Y.; Hou, C.; Duan, X.; Sheng, P.; Sandell, L.J.; Liao, W. Resistin stimulates expression of chemokine genes in chondrocytes via combinatorial regulation of C/EBP $\beta$ and NF- $\mathrm{kB}$. Int. J. Mol. Sci. 2014, 15, 17242-17255. [CrossRef]

79. Su, Y.P.; Chen, C.N.; Chang, H.I.; Huang, K.C.; Cheng, C.C.; Chiu, F.Y.; Lee, K.C.; Lo, C.M.; Chang, S.F. Low Shear Stress Attenuates COX-2 Expression Induced by Resistin in Human Osteoarthritic Chondrocytes. J. Cell. Physiol. 2017, 232, 1448-1457. [CrossRef] [PubMed]

80. Guan, P.P.; Guo, J.W.; Yu, X.; Wang, Y.; Wang, T.; Konstantopoulos, K.; Wang, Z.Y.; Wang, P. The role of cyclooxygenase-2, interleukin-1 $\beta$ and fibroblast growth factor-2 in the activation of matrix metalloproteinase-1 in sheared-chondrocytes and articular cartilage. Sci. Rep. 2015, 5, 10412. [CrossRef] 
81. Goldring, M.B.; Birkhead, J.R.; Suen, L.F.; Yamin, R.; Mizuno, S.; Glowacki, J.; Arbiser, J.L.; Apperley, J.F. Interleukin-1 beta-modulated gene expression in immortalized human chondrocytes. J. Clin. Invest. 1994, 94, 2307-2316. [CrossRef] [PubMed]

82. Finger, F.; Schörle, C.; Zien, A.; Gebhard, P.; Goldring, M.B.; Aigner, T. Molecular phenotyping of human chondrocyte cell lines T/C-28a2, T/C-28a4, and C-28/I2. Arthritis Rheum. 2003, 48, 3395-3403. [CrossRef] [PubMed]

83. Loeser, R.F.; Sadiev, S.; Tan, L.; Goldring, M.B. Integrin expression by primary and immortalized human chondrocytes: Evidence of a differential role for alpha1beta1 and alpha2beta1 integrins in mediating chondrocyte adhesion to types II and VI collagen. Osteoarthritis Cartilage 2000, 8, 96-105. [CrossRef] [PubMed]

84. Santoro, A.; Conde, J.; Scotece, M.; Abella, V.; Lois, A.; Lopez, V.; Pino, J.; Gomez, R.; Gomez-Reino, J.J.; Gualillo, O. SERPINE2 Inhibits IL-1 $\alpha$-Induced MMP-13 Expression in Human Chondrocytes: Involvement of ERK/NF-kB/AP-1 Pathways. PLoS ONE 2015, 10, e0135979. [CrossRef] [PubMed]

85. Cheleschi, S.; Calamia, V.; Fernandez-Moreno, M.; Biava, M.; Giordani, A.; Fioravanti, A.; Anzini, M.; Blanco, F. In vitro comprehensive analysis of VA692 a new chemical entity for the treatment of osteoarthritis. Int. Immunopharmacol. 2018, 64, 86-100. [CrossRef] [PubMed]

86. Jacques, C.; Holzenberger, M.; Mladenovic, Z.; Salvat, C.; Pecchi, E.; Berenbaum, F.; Gosset, M. Proinflammatory actions of visfatin/nicotinamide phosphoribosyltransferase (Nampt) involve regulation of insulin signaling pathway and Nampt enzymatic activity. J. Biol. Chem. 2012, 287, 15100-15108. [CrossRef] [PubMed]

87. Altman, R.; Alarcon, G.; Appelrouth, D.; Bloch, D.; Borestein, D.; Brandt, K.; Brown, C.; Cooke, T.D.; Daniel, W.; Feldman, D.; et al. The American College of Rheumatology criteria for the classification and reporting of osteoarthritis of the hip. Arthritis Rheumatol. 1991, 34, 505-514. [CrossRef]

88. Mankin, H.J.; Dorfman, H.; Lippiello, L.; Zarins, A. Biochemical and metabolic abnormalities in articular cartilage from osteo-arthritic human hips II. Correlation of morphology with biochemical and metabolic data. J. Bone Jt. Surg. Am. 1971, 53, 523-537. [CrossRef]

89. Ramakers, C.; Ruijter, J.M.; Deprez, R.H.; Moorman, A.F. Assumption-free analysis of quantitative real-time polymerase chain reaction (PCR) data. Neurosci Lett. 2003, 339, 62-66. [CrossRef]

90. Pfaffl, M.W. A new mathematical model for relative quantification in real RT-PCR. Nucleic Acid Res. 2001, 29, e45. [CrossRef]

91. Vandesompele, J.; de Preter, K.; Pattyn, F.; Poppe, B.; van Roy, N.; de Paepe, A.; Speleman, F. Accurate normalization of real-time quantitative RT-PCR data by geometric averaging of multiple internal control genes. Genome Biol. 2002, 3, research0034.1. [CrossRef]

92. Cheleschi, S.; Pascarelli, N.A.; Valacchi, G.; Di Capua, A.; Biava, M.; Belmonte, G.; Giordani, A.; Sticozzi, C.; Anzini, M.; Fioravanti, A. Chondroprotective effect of three different classes of anti-inflammatory agents on human osteoarthritic chondrocytes exposed to IL-1ß. Int. Immunopharmacol. 2015, 28, 794-801. [CrossRef] [PubMed]

(C) 2018 by the authors. Licensee MDPI, Basel, Switzerland. This article is an open access article distributed under the terms and conditions of the Creative Commons Attribution (CC BY) license (http:// creativecommons.org/licenses/by/4.0/). 